\title{
NOS VENTOS DO COMÉRCIO NEGREIRO: A PARTICIPAÇÃO DOS TRAFICANTES BAIANOS NAS PROCURAÇÕES PASSADAS NO TERMO DE VILA DO CARMO, $1711-1730$
}

Carlos Leonardo Kelmer Mathias

Doutorando em História-UFRJ/Bolsista CNPq

\section{Resumo}

O objetivo do artigo éestudar a participação dos traficantes resi dentes na capitania da Bahia nas escrituras de "procuração bastante" emitidas no termo de Vila do Carmo entre 1711 e 1725, excetuando o período entre 1721 e 1725. Essa documentação está sob custódia do Arquivo da Casa Setecentista de Mariana.

\section{Palavras-chave}

Procuração $\bullet$ tráfico $\bullet$ escravo.

\section{Abstract}

The article analyzes the participation of the slave traders living en captainship of Bahia in the letters of attorney emitted in the term of Vila do Carmo between 1711 and 1725, except the period between 1721 and 1725. That documentation is under guard of the archive of the Casa Setecentista de Mariana.

\section{Keywords}

Letter of attorney $\bullet$ trade $\bullet$ slave. 
Na maré das primeiras notícias dos achados de ouro na região das "minas gerais", teve vez e efeito o engendramento de vários circuitos mercantis nos quais, direta ou indiretamente, acabaram por tomar parte várias regiões do globo. De Goa às capitanias brasileiras, passando por Benguela, Luanda, Costa da Mina, Lisboa, Londres ou Amsterdã, todos, em diferentes graus, acabaram por se beneficiar das descobertas auríferas. Indubitavelmente, no comércio das almas repousa uma das principais chaves para a compreensão desse processo.

O presente artigo tem por objetivo lançar luz em alguns desses circuitos mercantis, notadamente aqueles mais diretamente envolvidos nas rotas do ouro. Em boa verdade, no bojo dos desvendamentos dos veios auríferos em regiões como Vila do Carmo, Vila Rica, Caeté e mesmo Sabará, concorreram portugueses, fluminenses, baianos e paulistas. Nada mais natural do que esperar serem esses os primeiros protagonistas atuantes em tais circuitos.

Nesses termos, a região mineradora não será aqui analisada de modo oblíquo, fechada em si mesma. Tampouco pretendo percebê-la subordinada a tal ou tal praça mercantil. No que respeita aos limites geográficos do Brasil colônia, entendo que as descobertas auríferas contribuíram para a formação de um eixo mercantil sediado, fundamentalmente, em três pontos, a saber: a cidade de Salvador, a comarca de Vila Rica e a cidade do Rio de Janeiro. Com isso, não pretendo excluir a inserção e atuação da capitania de São Paulo, de Pernambuco ou das demais comarcas componentes da capitania mineira desse eixo principal. Entre 1716 e 1717, o registro do Rio Grande, no caminho para São Paulo, respondeu pela maior parte dos gêneros de secos e de molhados que entraram em Minas. No mesmo período, o caminho do sertão da Bahia e Pernambuco destacou-se no abastecimento de escravos, totalizando cerca de 800. Sabe-se que, entre 1718 e 1719, 200 escravos entraram por este caminho para a Vila de Sabará, na comarca de Rio das Velhas. No que tange ao Rio de Janeiro, é seguro afirmar, segundo Ângelo Alves Carrara, que já em 1728 essa praça surge como o principal centro abastecedor da capitania mineira. ${ }^{1}$

Ao delimitar por central o eixo compreendido entre Salvador, comarca de Vila Rica e Rio de Janeiro, tenho em mente, como o próprio título do artigo sugere, o trato negreiro por norte. E isto se deve por algumas razões, dentre elas: 1) mesmo que o número total de fazendas secas e molhadas, cavalos, mulas e

${ }^{1}$ CARRARA, Ângelo Alves. Minas e currais: produção rural e mercado interno de Minas Gerais, 1674 - 1808. Juiz de Fora: Editora da UFJF, 2007, p. 117-119. 
gados que entrassem na capitania sobrepujassem o de escravos, dificilmente a soma daqueles valores superaria os valores oriundos das entradas de negros - fato provavelmente característico de toda sociedade baseada no tráfico de escravos $;{ }^{2}$ 2) durante o período ora analisado, os escravos responderam, em média, por $43,4 \%$ da composição das riquezas inventariadas no termo de Vila do Carmo; ${ }^{3}$ 3) o grosso do financiamento e do controle do tráfico atlântico de escravos escapava ao domínio metropolitano, transformando tal negócio na principal forma de acumulação endógena à colônia. ${ }^{4}$ Tal delineamento também justifica a não inclusão de São Paulo nesse eixo, uma vez que essa capitania não era uma das principais fornecedoras de escravos para a região das minas, cabendo a capitanias do Rio de Janeiro e Bahia/Pernambuco esse papel. Digase de passagem, não foi por nada que, dentre os 9.309 procuradores nomeados no termo de Vila do Carmo, apenas 4,09\% o foram para a região paulista, não obstante nem todas as procurações visarem atividades comerciais. A despeito dos efeitos provenientes da guerra dos Emboabas de 1709, creio repousar nessa não atuação da capitania paulista, como centro abastecedor de mão-de-obra escrava para a região das minas, o principal motivo para tão diminuta porcentagem.

\footnotetext{
${ }^{2}$ Segundo Antônio Carlos Jucá de Sampaio, havia um imposto específico sobre os escravos destinados à região das minas. Não obstante, também incidia uma taxa sobre a entrada dos mesmos na capitania, taxa essa inserida no imposto das "entradas". Sobre o primeiro ponto, ver SAMPAIO, Antônio Carlos Jucá de. Na encruzilhada do império: hierarquias sociais e conjunturas econômicas no Rio de Janeiro (c. 1650 - c. 1750). Rio de Janeiro: Arquivo Nacional, 2003, p. 151. Acerca do segundo, ver CÓDICE Costa Matoso. Belo Horizonte: Fundação João Pinheiro, vol. II, 1999. Coordenação-geral de Luciano Raposo de Almeida Figueiredo e Maria Verônica Campos, p. 95; ROMEIRO, Adriana \& BOTELHO, Ângela Vianna. Dicionário histórico das Minas Gerais: período colonial. Belo Horizonte: Autêntica, 2003, p. 106-108.

${ }^{3}$ KELMER MATHIAS, Carlos Leonardo. A cor negra do ouro: circuitos mercantis e hierarquias sociais na formação da sociedade mineira setecentista, c. 1711 - c. 1756. Rio de Janeiro: PPGHIS, 2007, cap. 3. ${ }^{4}$ Vale destacar que, no concernente ao Rio de Janeiro na primeira metade do século XVIII, o tráfico passou a ser progressivamente controlado pelos comerciantes fluminenses, sendo que havia uma rede de negócios na qual participavam também negociantes reinóis; mesmo porque, nas primeiras décadas do século XVIII, a comunidade de comerciantes atlânticos no Rio de Janeiro estava se formando. Segundo Pierre Verger, na Bahia, o controle do tráfico por traficantes residentes na cidade já ocorria há mais tempo. Ver SAMPAIO, op. cit., passim; VERGER, Pierre. Fluxo e refluxo: do tráfico de escravos entre o golfo do Benin e a Bahia de Todos os Santos dos séculos XVII a XIX. São Paulo: Corrupio, 1987; FLORENTINO, Manolo Garcia. Em costas negras: uma história do tráfico de escravos entre a África e o Rio de Janeiro. São Paulo: Cia. das Letras, 1997, cap. $4^{\circ} \mathrm{e}$ FRAGOSO, João. Homens de grossa aventura: acumulação e hierarquia na praça mercantil do Rio de Janeiro, 1790-1830. Rio de Janeiro: Civilização Brasileira, 1998, p. 159-160.
} 
Assim sendo, e em função dos "efeitos de arraste" causados pela mineração no conjunto da economia colonial brasileira, ${ }^{5}$ a delimitação do eixo aqui estabelecido se pauta pela noção de "espaço econômico", largamente empregada e debatida pela historiografia hipano-americana. Segundo Ângelo Carrara, e de forma resumida,

o espaço econômico equivale ao âmbito da circulação de mercadorias, à extensão dos circuitos mercantis. É exatamente este o seu conteúdo: a rede de circulação de mercadorias, o conjunto de lugares comercialmente articulados através de rotas determinadas. Se o mercado é o conjunto de relações mercantis, o espaço econômico é a expressão geográfica do mercado. ${ }^{6}$

Tal noção coaduna-se perfeitamente ao conceito de região expressado por Eric Van Young. Segundo o autor, uma região agrícola ou econômica não coincide necessariamente com as divisões políticas ou administrativas, nem mesmo com as topográficas. Dessa forma, a região adquire a dimensão de "um espaço geográfico com fronteiras determinadas pelo alcance efetivo de alguma classe de sistema cujas partes se inter-relacionam entre si mais do que com outras partes situadas fora do sistema". Nesses termos, a região é delimitada conforme a área de mercado e os circuitos mercantis os quais influenciam essa mesma área. ${ }^{7}$

No que respeita aos objetivos e enquadramentos da pesquisa em questão, percebo o eixo composto pela capitania da Bahia (e Pernambuco), pela comarca de Vila Rica e pela capitania do Rio de Janeiro como um único "espaço econômico" articulado, na sua essência, em função do tráfico negreiro e do ouro das minas. Tratam-se de rotas bastante específicas, concentradas ora em caminhos terrestres, ora em vias marítimas. Para além da parte americana, essas rotas englobavam, mais diretamente, a costa africana e a Índia, por intermédio de seus têxteis. Nesse emaranhado de redes e entrepostos comerciais, os circuitos mercantis ganhavam razão de ser ao ligarem diferentes paragens do globo entre si.

\footnotetext{
${ }^{5}$ A idéia de efeito de arraste é devedora da obra de Margarita Suárez, quem trabalhou tais efeitos para o conjunto da economia andina. Ver SUÁREZ, Margarita. Desafíos transatlánticos: mercaderes, banqueros y el estado en el Peru virreinal, 1600-1700. Peru: Fondo de Cultura Económica, 2001. ${ }^{6}$ Acerca da discussão da noção de "espaço econômico", ver CARRARA, op. cit., p. 54-55 [itálicos do autor].

${ }^{7}$ YOUNG, Eric Van. La cuidad y el campo en el México del siglo XVIII: la economía rural de la región de Guadalajara, 1675-1820. México: Fondo de Cultura Económica, 1989, p. 15-36.
} 
Segundo Fernand Braudel, "os circuitos mercantis são iguais aos circuitos elétricos: só funcionam fechados"; caso contrário, estão condenados a desaparecer. Conforme o autor, "sendo a troca reciprocidade, a cada trajeto de $\mathrm{A}$ a $\mathrm{B}$ corresponde uma certa volta, tão complicada e sinuosa quanto se queira, de B a A. A troca se fecha então sobre si própria. Há circuito". Porém, não escapa ao autor a dificuldade em se fechar tais circuitos - nos quais o crédito tem papel central -, muito menos a complexidade própria ao comércio triangular havido no Atlântico entre os séculos XVII e XVIII. ${ }^{8}$ O que dizer então dos traficantes brasileiros, os quais compravam têxteis em Salvador provenientes da Índia com intuito de os trocarem por escravos na costa de Benguela, retornarem ao Brasil para, enfim, vendê-los em Minas - por vezes via Rio de Janeiro - em troca de ouro?

Percebe-se a amplidão e complexidade dos circuitos mercantis que, muitas vezes, tinham na capitania mineira seu fim último. Homens interligados a agentes mercantis situados em vários pontos de vários circuitos, unidos pela conjuntura favorável dos descobrimentos auríferos, valeram-se do tráfico negreiro como principal - ou ao menos o mais rendoso - meio de acesso ao ouro. Já foi dito "que os grandes mercadores, embora pouco numerosos, se apoderaram das chaves do comércio de longa distância, a posição estratégica mais representativa”. Jogando com os preços de mercados distintos e afastados entre si, esses homens estavam aptos a obter os maiores lucros. ${ }^{9}$ Se assim for, os grandes traficantes e aqueles ligados ao financiamento de tais empresas surgiram como os beneficiários por excelência dos achados de finais do século XVII. Por conseguinte, e dentro do "espaço econômico" aqui determinado, as capitanias da Bahia e do Rio de Janeiro igualmente o foram.

\section{A geografia do tráfico atlântico de escravos}

Em 1723, os membros da câmara de Goa queixaram-se dos comerciantes baianos que conduziam o comércio de têxteis em Moçambique. Tal queixa referia-se a comerciantes como Baltazar Álvares de Araújo, agente baseado na Bahia a serviço de Francisco Pinheiro, quem enviou um carregamento de tecidos europeus de Salvador para Moçambique em 1719. ${ }^{10}$ Em 2 de julho de

\footnotetext{
${ }^{8}$ BRAUDEL, Fernand. Civilização material, economia e capitalismo, séculos XV-XVIII: os jogos das trocas. Vol. 2. São Paulo: Martins Fontes, 1996, p. 117-122.

${ }^{9}$ BRAUDEL, op. cit., p. 353-356.

${ }^{10}$ FERREIRA, Roquinaldo. Transforming atlantic slaving: Trade, warfare and territorial control
} 
1728, o capitão e senhor de escravos Antônio de Siqueira Rondon - dono, em sociedade com João Mateus Rondon, de um sítio com 21 escravos na freguesia de Camargos, ${ }^{11}$ termo de Vila do Carmo - nomeou, dentre outros, dois procuradores para a cidade da Bahia. ${ }^{12}$ Eram eles, o sargento-mor Luis Tenório de Molina e o comerciante Baltazar Álvares de Araújo. ${ }^{13}$ Além de ter sido homem poderoso atuante na capitania mineira nas primeiras décadas do século XVIII, ${ }^{14}$ o sargento-mor Luis Tenório de Molina estabeleceu sociedade com Manoel dos Santos Freitas, Caetano de Sousa Sá, Manoel Gonçalves Machado e Manoel da Costa Granja para uma empresa negreira em 1733, a qual desembarcou na Bahia cerca de 307 escravos. Conforme se verá, Manoel Gonçalves Machado atuou em outras quatro viagens negreiras entre 1721 e 1740, sendo responsável pelo desembarque na Bahia de 1.347 africanos. ${ }^{15}$

Não seria prudente afirmar ter havido qualquer tipo de ligação entre Antônio de Siqueira Rondon e os demais traficantes sócios de Luis Tenório de Molina, muito menos entre Siqueira Rondon e o comércio de têxteis em Moçambique. Sem embargo, delineiam-se circuitos em cujos meandros o ouro esvaia-se da

in Angola, 1650-1800. Los Angeles: Tese de doutorado, University of Califórnia, 2003, p. 61. Entre 1710 e 1713, pelo menos 10 navios saíram da Bahia diretamente para Moçambique, na Costa Oriental da África.

${ }^{11}$ Arquivo da Casa Setecentista de Mariana, Livro de nota 03, Escritura de compra e venda, 05/07/1714.

${ }^{12}$ Os procuradores eram indivíduos responsáveis por representarem os interesses do outorgante em toda e qualquer ação civil ou comercial. Apresento dois exemplos das incumbências dos procuradores. Após a relação dos indivíduos nomeados, segue: "mostradores que serão deste poder aos quais disse dava, e outorgava, cedia e trespassava todo o seu livre e comprido poder mandado geral e especial com bastante direito se requer e alegar todo seu direito e justiça para que por ele outorgasse em seu nome e como ele próprio em pessoa possam os ditos seus procuradores acima nomeados todos juntos ou qualquer deles de per se de cobrarem, receberem, acordarem e a seus poderes houve toda sua fazenda bens móveis e de raiz, dívidas, dinheiro, ouro, prata, açúcares, escravos, encomendas, carregação, seus (?) e coisas outras de qualquer qualidade". Por vezes se acrescia: "poderão apelar e agravar vir com embargos isentar suspeições a quaisquer juízes e oficiais de justiça, ouvir sentenças e das que forem a seu favor estar por elas, e das contra ele apelar e agravar e segui-las até moral cada, cobrarem, arrecadarem todas suas dívidas de todas as pessoas que obrigadas lhe forem, dar quitações públicas".

${ }^{13}$ ACSM, LN 29, Escritura de procuração bastante, 02/07/1728.

${ }^{14}$ KELMER MATHIAS, Carlos Leonardo. Jogos de interesses e estratégias de ação no contexto da revolta mineira de Vila Rica, c. 1709 - c. 1736. Rio de Janeiro: PPGHIS, 2005, passim (Dissertação de mestrado).

${ }^{15}$ ELTIS, David; BEHRENDT, Stephen; RICHARDSON, David; and KLEIN, Herbert. The transAtlantic slave trade: a Dataset on CD-ROM, 1999. ELTIS, David; BEHRENDT, Stephen; RICHARDSON, David; and FLORENTINO, Manolo. The Trans-Atlantic slave trade: a dataset on-line (TSTD). Agradeço a Alexandre Vieira Ribeiro por ter gentilmente me cedido o referido banco de dados. 
capitania e concorria para dar vida a esses mesmos circuitos. Nesses termos, a própria geografia do tráfico negreiro lança luz sobre os circuitos nos quais o ouro atuava.

O impacto das descobertas auríferas se fez sentir em várias partes do mundo setecentista. Particularmente no que respeita às pretensões do corrente artigo, interessa-me medi-lo junto ao tráfico negreiro. Aqui, não se pretende perceber a atuação dos traficantes brasileiros na costa africana de modo bipolar: por um lado, ter-se-iam os baianos e pernambucanos restritos à região da África Ocidental e, por outro, os fluminenses monopolizando o trato na África CentroOcidental. Nos dias de hoje, tal divisão não mais se sustenta. Já em 1703, d. Rodrigo da Costa, então governador-geral do Brasil, deu conta ao rei sobre o contrabando de ouro na Costa da Mina por intermédio de traficantes fluminenses. Escreveu d. Rodrigo:

os moradores do Rio de Janeiro, e das capitanias suas anexas, continuam a mandar, há poucos anos, várias embarcações a resgatar escravos a Costa da Mina, o que até agora não faziam... achei que a maior importância das duas carregações era ouro em pó e em barras; e que o negócio que haviam de fazer com os negros da dita Costa, levando para isso os gêneros costumados, o fazem com os estrangeiros [ingleses, franceses e holandeses] que nela V. Majestade, pela perda que isso tem, por ser certo que a maior parte do ouro que vai é por quintas, assim de não ser conveniente que os estrangeiros sejam senhores dele por troca de escravos que estão roubando às nossas embarcações. ${ }^{16}$

No mesmo ano veio a resposta régia proibindo que navios provenientes do Rio de Janeiro ou "dos portos das capitanias do sul" singrassem rumo à Costa da Mina, África Ocidental. ${ }^{17}$ Contudo, em nada adiantou a determinação régia, pois, entre 1722 e 1731, 113 navios aportaram no Recife provenientes da Costa da Mina, desembarcando cerca de 22.270 escravos. Em sua maioria, tais cativos foram adquiridos por intermédio do tabaco de terceira qualidade produzido na Bahia e em Pernambuco. A importância de tal gênero era tamanha que "os navios procedentes do Rio de Janeiro paravam em Recife para pegar tabaco antes de partirem para a África Ocidental”. Daqueles vinte e dois mil africanos

\footnotetext{
${ }^{16}$ Arquivo Estadual da Bahia, 07, doc. 108. Apud. VERGER, Pierre, op. cit., p. 39-40.

${ }^{17}$ AEB, 07, doc. 218. Apud, ibidem.
} 
aportados no Recife, muitos estavam endereçados à capitania fluminense, onde comerciantes residentes por lá os vendiam para senhores em Minas Gerais. Dessa forma, os traficantes pernambucanos resguardavam sua cota no ouro mineiro, utilizando parte deste para negociar na África Ocidental, novamente. ${ }^{18}$

Em 1721, dois navios aportaram no Rio de Janeiro provenientes da África Ocidental com cerca de 800 escravos, os quais foram vendidos em apenas dois dias. Entre 1722 e 1725, oito navios arribaram na capitania fluminense perfazendo um total de 2.642 negros provenientes da África Ocidental. Por fim, entre 1725 e 1727, 5.700 escravos chegaram ao Rio de Janeiro, todos procedentes da África Ocidental. Tendo em conta que não se produzia tabaco na capitania do Rio de Janeiro, esses comerciantes o adquiriam na Bahia e em Pernambuco de duas formas: ou no caminho para a África, ou importando-o previamente daquelas duas capitanias. ${ }^{19}$

A atuação de traficantes baianos e pernambucanos na região da África Centro-Ocidental também ocorria. Em meados do século XVIII, comerciantes com licença para irem resgatar africanos na Costa da Mina acabaram por fazêlo em Benguela. Ao que parece, esses homens, por vezes, atuavam em ambas as paragens. Foi o caso, por exemplo, de Manoel Alves de Carvalho que, entre 1749 e 1750, remeteu duas galeras para a África Ocidental e duas para a África Central Atlântica. Igualmente, João Lourenço Veloso despachou, entre os anos de 1745 e 1750, um navio para a região da Costa da Mina e outro para Benguela. ${ }^{20}$ Nesses termos, a tabela 1 não chega a causar muita estranheza.

\footnotetext{
${ }^{18}$ FERREIRA, op. cit., p. 94-95.

${ }^{19}$ Idem, p. 95-96.

${ }^{20}$ RIBEIRO, Alexandre Vieira. O tráfico atlântico de escravos e a praça mercantil de Salvador, 1680-1830. Rio de Janeiro: PPGHIS/UFRJ, 2005, p. 38 (Dissertação de mestrado inédita).
} 


\begin{tabular}{|c|c|c|}
\hline \multicolumn{3}{|c|}{$\begin{array}{c}\text { Tabela } 1 \\
\text { Distribuição }(\%) \text { dos escravos na capitania de Minas Gerais } \\
\text { conforme região de origem, 1713-1756 }\end{array}$} \\
\hline Região de origem & $\mathbf{N}^{\circ}$ de escravos & $\%$ \\
\hline África Ocidental & 2.538 & 60,4 \\
\hline África Centro-Ocidental & 1.595 & 37,96 \\
\hline África Oriental & 69 & 1,64 \\
\hline Total de escravos & 4.202 & 100 \\
\hline
\end{tabular}

Da produção de tabaco nas capitanias do Nordeste, baianos, pernambucanos e fluminenses se valeram para adquirir escravos na Costa da Mina. Naquelas paragens, além do comércio escravo-tabaco, o ouro levado clandestinamente nas barcas, galeras, bergantins e sumacas era comercializado, muitas vezes junto aos ingleses, aos franceses e mesmo aos holandeses. Na viagem de volta, após um primeiro desembarque em Recife ou em Salvador, seguido de transações comerciais, muitos dos escravos mareavam para o Rio de Janeiro, donde rumavam, alguns deles, para as Gerais. Ouro em troca de escravo. Pagamento à vista ou à prazo. E novamente os circuitos negreiros em que o ouro fluía eram postos na ordem do dia.

Se, por um lado, a tabela 1 revela ser bastante arriscado mensurar o peso das capitanias da Bahia, de Pernambuco e do Rio de Janeiro no abastecimento de Minas, conforme a região de origem dos escravos presentes nos inventários post-mortem - mesmo porque a porcentagem de escravos desembarcados na Bahia e em Pernambuco provenientes de Luanda, ao longo do século XVIII, se manteve relativamente estável, ainda que em proporções inferiores às do Rio de Janeiro $^{21}$-, por outro, lança luz sobre a importância do tabaco no engendramento dos circuitos negreiros nos quais o ouro fluía. Para além, a tabela indica que, não obstante o uso da geribita fluminense no trato com a África Centro-Ocidental, o

\footnotetext{
${ }^{21}$ MILLER, Joseph. A economia política do tráfico angolano de escravos no século XVIII. In: PANTOJA, Selma \& SARAIVA, José (orgs.). Angola e Brasil nas rotas do Atlântico Sul. Rio de Janeiro: Bertrand, 1999, p.56-61.
} 
tabaco em muito contribuiu para o estreitamento das ligações entre comerciantes do Rio de Janeiro, da Bahia e de Pernambuco, concorrendo, dessa forma, para a formação do "espaço econômico" aqui trabalhado.

Conforme a tabela 1, o tráfico negreiro na Costa da Mina foi bastante ativo nas primeiras décadas do século XVIII. Contudo, o comércio nessa região guardava, conforme já apontado por d. Rodrigo da Costa, o perigo do descaminho do ouro para os cofres de nações estrangeiras. No alvorecer do século XVIII, os ingleses, os franceses e os holandeses forneciam escravos aos navios portugueses em troca de ouro. ${ }^{22}$ A título de exemplo, entre 1720 e 1722, o diretor inglês da Royal African Company, em transação com José de Torres - um dos mais importantes traficantes residentes na praça de Salvador e com forte influência na costa africana -, formou três carregamentos de escravos; o primeiro em 1720, no valor de $£ 716-12-4 \frac{1}{2}$; o segundo em 1721, no valor de £759-12-3 e perfazendo um total de 99 escravos; o último em 1722, no valor de £1.380 para 234 escravos. ${ }^{23}$ Com essa aproximação, os ingleses obtinham ouro e tabaco provenientes das capitanias de Minas Gerais e da Bahia. ${ }^{24}$

Recorrentemente, navios negreiros brasileiros eram alvos de apreensões e saques por parte dos holandeses. Tais incursões acabaram por gerar menores expectativas de sucesso na empresa traficante, contribuindo para uma diminuição das viagens. Segundo Alexandre Vieira Ribeiro,

ao iniciar a década de vinte inverteu-se a tendência de crescimento das saídas de negreiros de Salvador observadas nas primeiras décadas do século. Entre os anos de 1708-1712 o número médio era de aproximadamente 25 expedições realizadas por ano, total que subiu para uma média anual de 30 no lustro de 1713-1717. No qüinqüênio seguinte (1718-1722) essa média caiu para 20 chegando a apenas 10 partidas anuais no período de $1733-1737 .^{25}$

A situação agravou-se a tal ponto que, em 25 de maio de 1731, proibiram-se os navios brasileiros de comercializarem com os holandeses no castelo de São Jorge da Mina. Porém, em 20 de maio de 1734, o vice-rei escrevia para Lisboa

\footnotetext{
${ }^{22}$ VERGER, op. cit., p. 39.

${ }^{23}$ VERGER, op. cit., p. 44-45.

${ }^{24}$ Idem, p. 137.

${ }^{25}$ RIBEIRO, op. cit., p. 24-25.
} 
dando conta que "as embarcações do Brasil continuavam a ir ao castelo da Mina para pagar os direitos impostos pelos holandeses". ${ }^{26}$ Valendo-se de seus direitos exclusivos comerciais estabelecidos desde meados do século XVII, os holandeses cobravam uma taxa de $10 \%$ sobre o fumo levado pelos traficantes brasileiros a ser comercializado na Costa da Mina. ${ }^{27}$ Entre 1715 e 1756, nada menos que quinhentos navios pagaram a referida taxa aos batavos, o que não impediu o ataque holandês a vários navios provenientes do Brasil. ${ }^{28}$ Porém, não somente o tabaco era o alvo dos holandeses. Em carta de meados da década de 1730, o desembargador Wenceslau Pereira da Silva, em parecer enviado ao reino acerca dos "meios convenientes para suspender a ruína dos três principais gêneros do comércio do Brasil”, deu conta da forma pela qual o ouro escoava para os cofres holandeses. Escreveu o desembargador:

muito mais proveitoso é aquele negócio [o comércio da Costa da Mina] para os holandeses e zelandeses interessados na Companhia da Mina que tem ali estabelecido o seu comércio com os negros, os provém de gêneros e drogas, de que se agradam, de que se escolhem e no que interessam grandes avanços, revendendo-os depois aos nossos portugueses a troco de ouro. O mesmo negócio fazem negros instruídos pelos holandeses, a cujas mãos vai parar o ouro que se extrai do Brasil. ${ }^{29}$

Os achados auríferos em Minas também causaram um impacto no tráfico na Costa Centro-Ocidental. Em Luanda, por exemplo, os mercadores souberam jogar com a variação do preço do escravo nas diferentes cidades do Brasil. O aumento do preço no Rio de Janeiro levou os comerciantes a diminuírem o envio de navios para a Bahia e Pernambuco. Em 1699, um comboio de navios com destino à capitania de Pernambuco alterou sua rota para a capitania fluminense, pois "nenhum comerciante quis despachar escravos para o nordeste brasileiro". O mesmo fez o governador de Angola, Luiz César de Menezes homem profundamente envolvido com o comércio negreiro -, em relação a um de seus navios envolvidos no tráfico. Em 1700, Menezes deu conta a seu agente sediado em Pernambuco de que a demanda por escravos no Rio era o centro

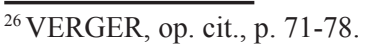

${ }^{27}$ Acerca de tais direitos comerciais ver VERGER, op. cit., notadamente capítulos I e II.

${ }^{28}$ FERREIRA, op. cit., p. 89.

${ }^{29}$ Arquivo Histórico Ultramarino, doc. da Bahia 347. Apud: VERGER, op. cit., p. 91-94.
} 
de gravidade por detrás do tráfico em Luanda. Nesses termos, não obstante as várias tentativas lisboetas de impedir tal redirecionamento na geografia do tráfico, os navios continuavam a navegar para o Rio em detrimento da Bahia e Pernambuco. Mesmo aqueles os quais aportavam nas capitanias do Nordeste enviavam seus escravos para a capitania fluminense quer por terra, quer por mar, perfazendo, no início do século XVIII, cerca de 6.000 escravos desembarcados na praça do Rio de Janeiro. ${ }^{30}$

A concordar com Roquinaldo Ferreira, o ouro foi peça fundamental no tráfico negreiro. Segundo o autor, em 1722, o vice-rei, Vasco César de Menezes, estimou em 90 arrobas o total de ouro levado anualmente para a África a partir dos portos brasileiros. Entre 1724 e 1728, conforme Robin Law, 5.845 onças (56:112\$000) foram utilizados na compra de escravos junto a mercadores britânicos. ${ }^{31} \mathrm{Na}$ Bahia, os senhores de engenho, além de se queixarem dos altos preços dos escravos, davam conta de que os traficantes preferiam vender os negros "aos mineradores, que pagavam em ouro, e não a eles, que só podiam pagar em açúcar ou em promessas baseadas na safra do ano seguinte". ${ }^{32}$

Analisando uma junta formada em 1735 pelo governador do Rio de Janeiro "com a intenção de decidir sobre a manutenção, ou não, do envio de ouro, prata e dinheiro para a África" - no que se acordou "permitir aos ditos homens de negócio fazerem as remessas que lhes pediam seus constituintes das peças de ouro e prata e dinheiro", ${ }^{33}$ não obstante o fato de que os metais preciosos enviados para Angola acabavam por serem direcionados para os navios de nações estrangeiras-, Antônio Carlos Jucá conclui:

essa decisão, que só é surpreendente para aqueles que ainda acreditam na miragem do "exclusivo metropolitano", mostrava-se absolutamente coerente com a necessidade de se preservar o fluxo contínuo de escravos que se destinavam à capitania fluminense, como também às regiões mineradoras. ${ }^{34}$

\footnotetext{
${ }^{30}$ FERREIRA, op. cit., p. 35-39. Acerca do envio de escravos de Pernambuco e Bahia para o Rio ver também SAMPAIO, op. cit., p. 170-173.

${ }^{31}$ FERREIRA, op. cit., p. 96-97.

${ }^{32}$ SCHWARTZ, Stuart. Segredos internos: engenhos e escravos na sociedade colonial. São Paulo: Companhia das Letras, 2005, p. 166.

${ }^{33}$ ARQUIVO NACIONAL, Publicações históricas, v. 7, p. 122. Apud: SAMPAIO, op. cit., p. 165. ${ }^{34}$ SAMPAIO, op. cit., p. 166.
} 
Assim sendo, o tráfico negreiro e o ouro das Gerais acabavam por incitar circuitos mercantis que, além de escaparem ao controle metropolitano, concorriam para unir - ou reforçar uniões preexistentes -, diferentes paragens do globo. Os comerciantes da Ásia igualmente procuravam lucrar com o comércio de escravos em Angola. Consoante Joseph Miller, sem o apoio financeiro inglês, o qual facultaria aos comerciantes asiáticos o acesso direto ao ouro brasileiro, esses negociantes perceberam, no comércio com o Rio de Janeiro, uma alternativa para tanto. Segundo o autor, "aproveitando-se do que parecia ser uma demanda insaciável por algodão indiano na África, eles [os comerciantes asiáticos] compraram escravos em Luanda e os venderam por ouro na América". ${ }^{35}$ Porém, não se pode perder de vista a utilização da cachaça fluminense no tráfico negreiro. Além de constituir o "maior volume na transação dos comerciantes do Rio em suas trocas por escravos angolanos", a cachaça garantia àqueles traficantes "um papel autônomo no tráfico angolano, quase intocável pelo poder do capital comercial metropolitano em Luanda". ${ }^{36}$

Conforme anteriormente enunciado, os têxteis indianos também desempenharam destacado papel nesses circuitos mercantis. Roquinaldo Ferreira chega a comparar sua importância à geritiba e ao tabaco. Todavia, destaca uma forte diferença nos circuitos envolvendo tais bens. Enquanto os dois últimos foram comercializados diretamente entre Brasil e África, as importações dos têxteis provenientes da Ásia estavam ligadas a redes comerciais com dimensões além do Atlântico Sul, unindo Portugal, Brasil e Ásia - a carreira da Índia. E chama a atenção para o fato segundo o qual, na busca por uma melhor compreensão de como esses têxteis intensificaram o comércio direto entre Brasil e Angola, não se pode prescindir de compreender as transformações ocorridas na carreira da Índia. ${ }^{37}$

De acordo com o acima exposto, não é nenhuma novidade na historiografia o fato de que as descobertas auríferas engendraram vários circuitos mercantis os quais ligavam diferentes partes do globo e nos quais o ouro esvaia-se para outros países. O que pretendi com tal exposição foi demonstrar a importância de se manter agentes mercantis em paragens nevrálgicas a tais circuitos, notadamente Salvador (Recife), Rio de Janeiro, Costa da Mina, Luanda (Benguela). Entendo que tal importância se deveu a um fator bastante simples: no que respeita à pri-

\footnotetext{
${ }^{35}$ MILLER, op. cit., p. 19.

${ }^{36}$ Idem, p. $25-26$.

${ }^{37}$ FERREIRA, op. cit., p. 50-51.
} 
meira metade do século XVIII, nas veias dos circuitos mercantis negreiros corria, em essência, o ouro da capitania mineira. Quanto menos para obter escravos, por detrás do tabaco, da geritiba e mesmo dos têxteis indianos, pulsava o desejo latente de reter para si parte do que se extraia em regiões como Vila do Carmo, Vila Rica, Vila Nova da Rainha do Caeté e Vila Nova de Nossa Senhora da Conceição de Sabará. E a possibilidade de lucro era imensa. Por exemplo, em 1688, a geritiba brasileira que chegava a Luanda era comercializada por $2 \$ 250$ por barril. ${ }^{38} \mathrm{Em}$ meados do século XVIII, um escravo era resgatado na costa africana por $6 \$ 000 . .^{39}$ Entre 1711 e 1720 , um escravo no Rio de Janeiro custava, em média, cerca de $197 \$ 609$, sendo que na Bahia valia, aproximadamente, $180 \$ 000 .{ }^{40}$ No termo de Vila do Carmo para o mesmo período, um escravo era vendido, em média, por $345 \$ 399 .{ }^{41}$

Em 1715, o sobrinho e agente de Francisco Pinheiro, Antônio Pinheiro Neto, deu conta de um carregamento de escravos procedente da Costa da Mina e vendido no Rio de Janeiro. Após terem sido subtraídos $97 \$ 420$ referentes a despesas com escravos e 1:322\$902 concernentes ao capitão do navio, ao agente mercantil e ao caixeiro, restou líquido para Francisco Pinheiro 9:667\$198. ${ }^{42}$

Conforme observado anteriormente, além de altamente lucrativo, o "comércio da carne humana" consistia em um dos principais meios de acumulação endógena à colônia - nesse processo, o ouro ocupou o papel central. Longe de ter sido remetido integralmente para Portugal, Inglaterra, Holanda ou qualquer outra paragem, parte do ouro produzido na colônia permaneceu na colônia. E o fez via tráfico negreiro, fechando vários circuitos mercantis nos quais atuavam traficantes e agentes mercantis residentes em diferentes partes do globo.

\footnotetext{
${ }^{38}$ CURTO, José. Vinho verso cachaça: a luta luso-brasiliera pelo comércio de álcool e de escravos em Luanda. In: PANTOJA, Selma \& SARAIVA, José (orgs.), op. cit., p. 82.

${ }^{39}$ RIBEIRO, op. cit., p. 77.

${ }^{40}$ SAMPAIO, Antônio Carlos Jucá de. A produção da liberdade: padrões gerais das manumissões no Rio de Janeiro colonial, 1650-1750. In: FLORENTINO, Manolo (org.). Tráfico, cativeiro e liberdade: Rio de Janeiro, séculos XVII-XIX. Rio de Janeiro: Civilização Brasileira, 2005, p. 298 e SCHWARTZ, Stuart. Alforria na Bahia, 1684-1745. In: Escravos, roceiros e rebeldes. São Paulo: Edusc, 2001, p. 210, respectivamente. Ambos autores retiram os valores médios a partir do valor pago por um escravo adulto do sexo masculino para obter sua liberdade.

${ }^{41}$ ACSM, LN 01-15, ECV.

${ }^{42}$ GUIMARÃES, Carlos Gabriel. O fidalgo-mercador Francisco Pinheiro e o "negócio da carne humana”, 1707-1715 (mimeo), p. 22. O texto encontra-se publicado em GUIMARÃES, C. G. O fidalgo-mercador Francisco Pinheiro e o negócio de carne humana, 1707-1715. In: Promontoria. Algarve, 2005, p. 109-134.
} 
Nesses circuitos, o ouro saía, quer transfigurado em tabaco, em geritiba ou em tecidos indianos, quer em sua forma natural, para, então, voltar tingido de preto. Uma vez aqui, via Bahia, Pernambuco e Rio de Janeiro, recobrava seu brilho dourado. ${ }^{43}$

\section{A conformidade das procurações}

Documentação ainda pouco trabalhada na historiografia brasileira para o período colonial, as escrituras de "procuração bastante" são valiosos registros das interações político-econômicas de uma dada localidade. Mais precisamente, permitem traçar o mapa geográfico de tais interações. Dentre as informações de maior importância oferecidas por tal documentação estão: o nome do outorgante, o local de sua residência, o nome dos procuradores e a localidade para a qual estavam sendo nomeados. Infelizmente, nas procurações registradas no termo de Vila do Carmo não constavam o ofício do outorgante, mas tão-somente sua patente militar. Por vezes, registrava-se se o indivíduo era padre, doutor ou escravo forro. Igualmente lamentável é a ausência do ofício dos nomeados procuradores. Para suprir tal lacuna, busquei identificar os traficantes de escravos nomeados para a capitania da Bahia junto ao banco de dados TSTD. Outra informação raramente registrada nas procurações era a finalidade específica para a qual um dado indivíduo estava sendo nomeado procurador - excetuam-se as procurações de casamento. Mormente, concedia-se plenos poderes ao procurador para cuidar dos interesses do outorgante nos campos políticos, jurídicos e econômicos. ${ }^{44}$ Feitos tais esclarecimentos, apresento o padrão das procurações passadas para o Rio de Janeiro, Bahia, Reino e São Paulo.

Segundo Alexandre Vieira Ribeiro, por volta de 1725, a participação baiana no abastecimento de escravos para a região das minas perdeu espaço para a capitania fluminense. ${ }^{45}$ De principal centro abastecedor de mão-de-obra - logo com maiores possibilidades de participação no ouro da capitania mineira -, a

\footnotetext{
${ }^{43}$ Saliento que não estou a desconsiderar todo o comércio de abastecimento alimentício voltado para a capitania de Minas Gerais. Porém, não creio que tal comércio sobrepujasse, em termos de valores e lucros, os circuitos mercantis provenientes do tráfico negreiro. A aquiescer com Antônio Carlos Jucá de Sampaio, produzir alimentos para a região das minas figurava "como a melhor forma para muitos de participar, ainda que fracamente, da conjuntura extremamente favorável por que passava a capitania". SAMPAIO, Antônio Carlos. Na encruzilhada do império..., op. cit., p. 133 [grifos meus].

${ }^{44}$ Para um exemplo de procuração ver nota 12.

${ }^{45}$ RIBEIRO, op. cit., p. 27.
} 
Bahia passou a desempenhar "um papel complementar para o atendimento da demanda na região das Gerais" ${ }^{46} \mathrm{O}$ gráfico 1.1 traz à baila a participação das quatro principais regiões externas à capitania mineira nas procurações emitidas a partir do termo de Vila do Carmo.

\section{Gráfico 1 - Participação das quatro principais regióes externas à capitania mineira nas procurações emitidas a partir do termo de Vila do Carmo, 1711-1730}

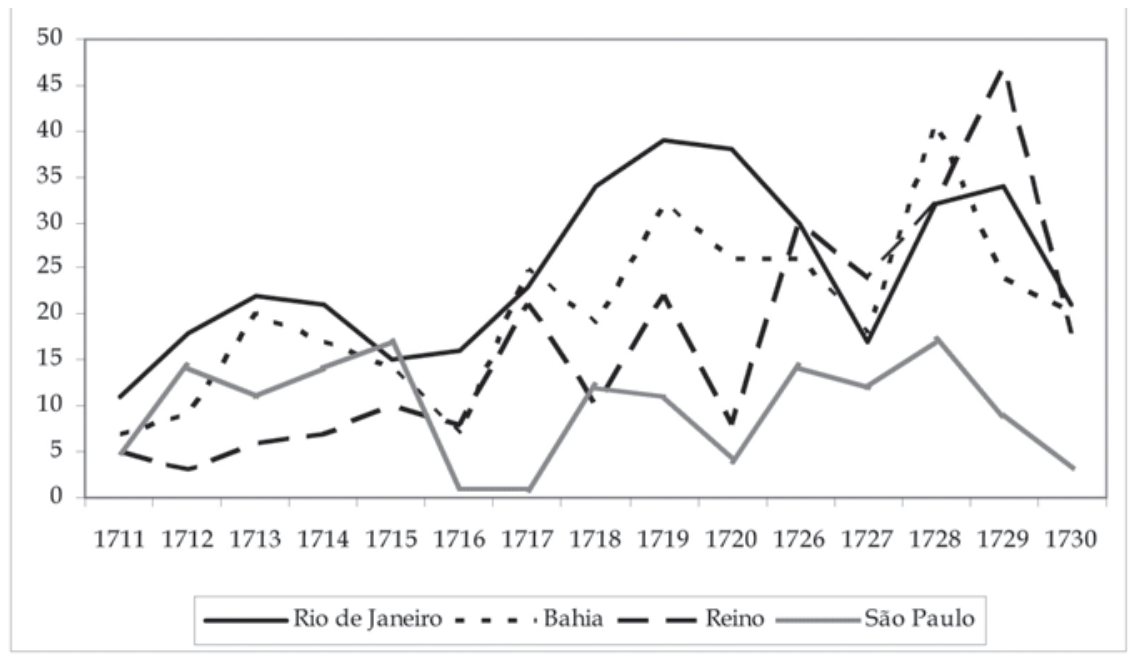

Fonte: ACSM, LN 1-15 e 25-35, EPB.

De saída, faz-se necessário uma rápida explicação da metodologia adotada na montagem do gráfico acima. Em primeiro lugar, um outorgante poderia nomear em uma mesma escritura mais de um procurador para várias localidades. Diga-se de passagem, essa prática revelou-se bastante comum na análise de tal documentação. A título de exemplo, em 11 de julho de 1711, João Romeu de Carvalho registrou uma escritura de procuração com a qual nomeou quarenta e quatro procuradores distribuídos da seguinte maneira: nove para a cidade da Bahia, quatro para os currais do rio São Francisco - comarca do Rio das Velhas

\footnotetext{
${ }^{46}$ RIBEIRO, Alexandre Vieira. O comércio transatlântico de escravos da Bahia, p. 10. Trata-se da versão em português do texto inédito do autor, o qual será publicado, posteriormente, em um livro organizado por David Eltis a ser editado pela Yale. Agradeço a Alexandre Vieira Ribeiro por ter gentilmente me facultado o acesso ao texto em questão.
} 
-, quatro para a vila de Cachoeira - capitania da Bahia -, três para a vila de Jaguaripe - capitania da Bahia -, quatro para a cidade do Rio de Janeiro, nove para a cidade de São Paulo, quatro para regiões internas de Minas Gerais, quatro para a cidade de Lisboa, um para a vila de Viana - distrito de Braga - e dois para a região de Angola. ${ }^{47}$ No exemplo acima, considerei três nomeações para a região da Bahia, uma para o Rio de Janeiro, uma para São Paulo, duas para o reino e uma para a África.

A opção por tal metodologia justifica-se na medida em que entendo a nomeação de diferentes procuradores para diferentes localidades de uma mesma capitania como indicativa da diversidade de interesses do outorgante na capitania em questão. Ademais, creio que a escolha empreendida contribui para um melhor detalhamento da importância e da inserção das diversas regiões no quadro mais geral estabelecido a partir da análise do perfil das procurações passadas no termo de Vila do Carmo. Assim sendo, o gráfico acima não mensura a porcentagem de participação das regiões consideradas frente ao total de escrituras. Mas, tãosomente a freqüência com que tais regiões aparecem nas procurações.

Em segundo lugar, urge destacar o caráter conjuntural dos dados apresentados. Afora a lacuna concernente ao período entre 1721 e $1725,{ }^{48}$ não me é permitido, por exemplo, tecer maiores considerações sobre o comportamento das capitanias da Bahia e Pernambuco nas procurações para o período posterior a 1730. Conforme o gráfico em questão, essas capitanias fecham o qüinqüênio de 1726-1730 com uma orientação decrescente nas suas participações frente ao total das escrituras. Se esse quadro tende a permanecer ou não, é impossível averiguar no presente momento da pesquisa.

Passando ao gráfico em si, observa-se que das 1.013 escrituras de procuração passadas no termo de Vila do Carmo entre 1711 e 1730 - com intervalo dos anos compreendidos entre 1721 e 1725 -, em 30\% delas foram nomeados procuradores para as capitanias da Bahia e de Pernambuco. Em detalhe, para o período de 1711 até 1720, as regiões da Bahia e Pernambuco responderam por 176 aparições frente a um total de 611 escrituras. Posteriormente, entre 1726 e 1730, tem-se 129 citações para 402 escrituras. Em verdade, longe de uma diminuição da participação daquelas regiões nas procurações passadas no termo de Vila do Carmo - o que seria de se esperar tendo em conta a perda de

\footnotetext{
${ }^{47}$ ACSM, LN 01, EPB , 01/07/1711.

${ }^{48}$ Ressalto que futuramente a pesquisa empreendida suprirá o período em questão.
} 
espaço no abastecimento de escravos em relação à capitania fluminense -, o que se observa é um aumento no percentual da freqüência de nomeações para as capitanias da Bahia e de Pernambuco - de $28,8 \%$ no primeiro período para $32,08 \%$ no segundo. A explicação para esse aparente paradoxo reside, quiçá, na própria flutuação dos desembarques de escravos na capitania. A tabela 2 avança nesse sentido.

Conforme a tabela, até o início da década de 1720, o afluxo anual de africanos para a capitania baiana, embora apresentando uma linha cujo desempenho aponte para um decrescimento, manteve-se elevado. Após um período de queda em tal afluxo, o número de desembarques na região, entre a segunda metade da década de vinte até o início da seguinte, passou por um revigoramento, para então ser sobrepujado pela capitania fluminense nos anos vindouros. ${ }^{49}$

\begin{tabular}{|c|c|c|}
\hline \multicolumn{3}{|c|}{$\begin{array}{l}\text { Tabela } 2 \text { - Número de escravos desembarcados nas capitanias da Bahia e } \\
\text { Rio de Janeiro, 1710-1732 }\end{array}$} \\
\hline Ano & Bahia & Rio de Janeiro \\
\hline 1711 & 5350 & 4200 \\
\hline 1712 & 7624 & 4200 \\
\hline 1713 & 8782 & 4200 \\
\hline 1714 & 8564 & 4200 \\
\hline 1715 & 6542 & 4200 \\
\hline 1716 & 6977 & 4200 \\
\hline 1717 & 7231 & 4200 \\
\hline 1718 & 6072 & 4200 \\
\hline 1719 & 5542 & 4200 \\
\hline 1720 & 4556 & 4200 \\
\hline 1721 & 5673 & 4200 \\
\hline 1722 & 4736 & 4200 \\
\hline 1723 & 4381 & 4200 \\
\hline 1724 & 4866 & 4200 \\
\hline 1725 & 4496 & 4200 \\
\hline 1726 & 7211 & 5700 \\
\hline 1727 & 5659 & 5700 \\
\hline 1728 & 5659 & 5700 \\
\hline 1729 & 3743 & 5700 \\
\hline 1730 & 6783 & 5700 \\
\hline 1731 & 3591 & 3250 \\
\hline 1732 & 5135 & 3103 \\
\hline \multicolumn{3}{|c|}{ Fonte: RIBEIRO, op. cit., p. 127-131. } \\
\hline
\end{tabular}

Infelizmente, não disponho dos dados relativos às procurações para o intervalo de 1721 e 1725. Contudo, creio ser possível atrelar o aumento percentual

\footnotetext{
${ }^{49}$ Para o movimento de africanos desembarcados nas capitanias da Bahia e do Rio de Janeiro a partir de 1732 ver RIBEIRO, Alexandre Vieira. O tráfico atlântico de escravos..., op. cit., p. 127-131.
} 
da participação das capitanias da Bahia e de Pernambuco nas procurações passadas no termo de Vila do Carmo, entre 1726 e 1730, a esse revival do número de escravos importados vivido na região entre 1726 e 1728. Ainda mais tendo em conta que das 245 escrituras nomeadas para a cidade da Bahia, em 21,22\% delas os procuradores eram traficantes de escravos. ${ }^{50}$

Ademais, o cruzamento do gráfico 1 com a tabela 2 revela um dado digno de nota. Conforme o primeiro, em $36,62 \%$ das procurações ora analisadas foram nomeados procuradores para a capitania do Rio de Janeiro. Tal constatação ganha relevo quando se comparam as freqüências das capitanias da Bahia e de Pernambuco com a fluminense. De acordo com o acima exposto, para os períodos de 1711-1720 e 1726-1730, as primeiras capitanias responderam, respectivamente, por $28,8 \%$ e $32,08 \%$ das nomeações. Para a capitania do Rio de Janeiro, essas porcentagens são de 38,78\% e 33,33\%. Porém, a tabela 2 revela que durante todo o período compreendido entre 1711 e 1732, em somente um ano - 1729 - o número de escravos desembarcados no porto do Rio superou em grande medida aqueles desembarcados na Bahia. Se somente por volta do final da década de 1720 o Rio superou a Bahia como o principal centro abastecedor de Minas, os dados acerca da freqüência das procurações emitidas no termo de Vila do Carmo ganham uma dimensão inusitada.

Pode-se argumentar, por exemplo, que a proibição da circulação de mercadoria pelo caminho do Sertão da Bahia entre 1699 e 1714 tenha contribuído para tal perfil. ${ }^{51}$ Contudo, e conforme os gráficos 1 e 2, mesmo para o período posterior a 1714, quando o caminho é novamente liberado, a capitania fluminense permanece superando a baiana nas procurações passadas no termo de Vila do Carmo. Outra possível objeção seria relacionada à metodologia empregada na elaboração do gráfico 1, que poderia promover uma distorção nos dados. Nesse sentido, apresento o gráfico 2 .

\footnotetext{
${ }^{50}$ Cheguei a tal porcentagem promovendo o cruzamento dos 1.214 nomes de procuradores nomeados para a cidade da Bahia com os traficantes listados no banco de dados TSTD, entre 1691 e 1740; acerca do mesmo conferir nota 15 .

${ }^{51}$ Acerca da proibição e liberação do caminho, ver CARRARA, op. cit., p. 124-132 e CAMPOS, Maria Verônica, Governo de mineiros: "de como meter as Minas numa moenda e beber-lhe o caldo dourado”, 1693 a 1737. São Paulo: USP, FFLCH, 2002, p. 136-137 (Tese de doutoramento inédita).
} 


\section{Gráfico 2}

Participação (\%) das quatro principais regiões externas à capitania mineira nas procurações emitidas a partir do termo de Vila do Carmo conforme o número de procuradores nomeados, 1711-1730

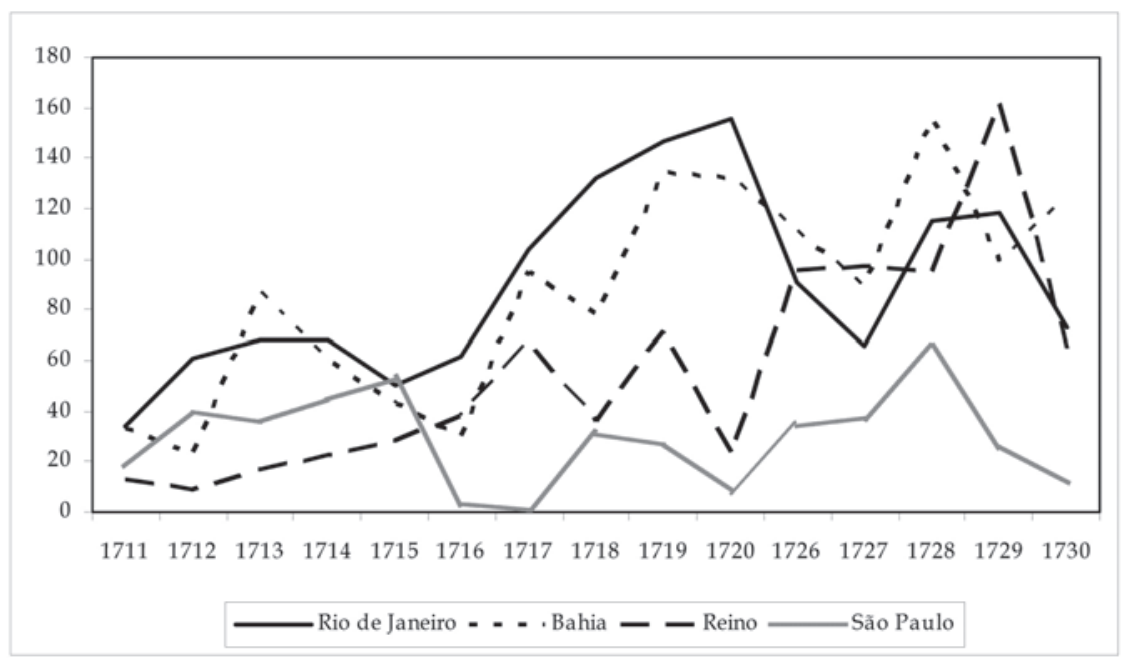

Fonte: ACSM, LN 1-15 e 25-35, EPB.

Não obstante a superação de procuradores nomeados para as capitanias baianas e pernambucanas frente à fluminense na segunda metade da década de vinte - fato surpreendente que pode ser atribuído ao revival do tráfico naquelas regiões -, o gráfico 2 torna bastante clara a supremacia da capitania fluminense frente às capitanias da Bahia e de Pernambuco. Essa preponderância do Rio de Janeiro sobre as regiões do Nordeste deixa de causar estranheza considerando, por exemplo, o movimento das mercadorias conforme os registros de entrada em Minas.

Pela tabela 3, percebe-se que, desde meados da década de 1710, se o Rio de Janeiro não era o principal centro abastecedor da capitania mineira - dado que a capitania de São Paulo valia-se do caminho Velho -, já dava sinais de assumir as formas de uma das "principais encruzilhadas do império". ${ }^{52} \mathrm{E}$ é exatamente no processo a partir do qual a capitania fluminense viria a se tornar uma das mais importantes paragens do império que reside o segredo do elevado número de procurações e procuradores nomeados para a capitania já a partir de 1711.

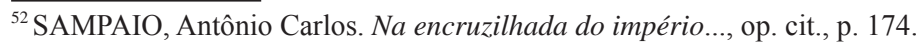


Não é por nada que, das 371 procurações passadas para o Rio de Janeiro, em $55,79 \%$ delas foram nomeados ou homens de negócio ou mercadores, e em $36,65 \%$, senhores de engenho. ${ }^{53}$

\begin{tabular}{|c|c|c|}
\hline \multicolumn{3}{|c|}{ Tabela 3 } \\
Importação de mercadorias pela capitania de Minas, 1716-1717 \\
\hline Discriminação & Caminhos Novo e Velho & Caminho do Sertão da Bahia \\
\hline Secos & 1.165 & 210 \\
\hline Molhados & 8.887 & 1.350 \\
\hline Escravos & 269 & 778 \\
\hline Fonte: CARRARA, op. cit., p. 117. \\
\hline
\end{tabular}

A fim de uma melhor aproximação da importância dos circuitos mercantis negreiros no abastecimento de escravos para a região de Minas, valho-me dos dados provenientes dos valores dos contratos de arrematação das entradas para Minas, ${ }^{54}$ dos valores dos contratos dos direitos dos escravos que vão para a capitania e dos movimentos de entrada de escravos nas capitanias do Rio de Janeiro e da Bahia. Segundo Alexandre Ribeiro Vieira, a partir de 1732, o número de escravos desembarcados no porto do Rio de Janeiro superou de forma definitiva aqueles desembarcados no porto de Salvador. ${ }^{55} \mathrm{Se}$ a isso somarmos, conforme dados de Maurício Goulart, que entre 1739 e 1759, dos cerca de 6.000 escravos enviados anualmente para a capitania de Minas, a capitania fluminense foi responsável por $65 \%$ do total, ficando os outros 35\% a cargo da capitania baiana, ${ }^{56}$ os valores dos contratos dos direitos dos escravos que vão para Minas ganham uma natureza amplamente contraditória. Consoante Antônio Carlos

\footnotetext{
${ }^{53}$ Tais porcentagens somente puderam ser obtidas graças ao esforço do professor Antônio Carlos Jucá de Sampaio em cruzar os procuradores nomeados para a capitania do Rio de Janeiro por mim encontrados com os seus próprios dados, esforço pelo o qual sou imensamente grato.

${ }^{54}$ Tratava-se de um "contrato de arrecadação do tributo sobre mercadorias que entram nas regiões mineradoras da América portuguesa, cuja cobrança se faz nos registros ou contagens. As tarifas são diferenciadas para os diversos tipos de mercadorias e bens, incidentes inclusive sobre os escravos". CÓDICE Costa Matoso, op. cit., vol. II, p. 88-89 e p. 94. Ver também ROMEIRO, Adriana \& BOTELHO, Ângela Vianna, op. cit., p. 106-107.

${ }^{55}$ RIBEIRO, Alexandre Vieira. O tráfico atlântico de escravos..., op. cit., p. 27.

${ }^{56}$ GOULART, Maurício. Escravidão africana no Brasil: das origens à extinção do tráfico. São Paulo: Alfa-Ômega, 1975, p. 170. Apud: RIBEIRO, Alexandre Vieira. O comércio transatlântico de escravos da Bahia, p. 10.
} 
Jucá de Sampaio, nunca, entre 1725 e 1748, o valor dos contratos dos direitos dos escravos arrematados no Rio de Janeiro superaram o valor dos mesmos na Bahia. Ou a capitania fluminense possuía uma incrível capacidade de absorver os 6.323 escravos os quais em média desembarcaram na capitania entre 1725 e $1748,{ }^{57}$ ou a explicação para esses números reside em outro ponto.

Observando os valores dos contratos das entradas para Minas, Antônio Carlos Jucá observa, a partir de 1727, uma forte superação no valor dos contratos dos caminhos Novo e Velho em relação ao caminho do Sertão da Bahia e Pernambuco. ${ }^{58}$ Se os valores das arrematações desses contratos servem como indicativo da superação de tal ou tal praça no abastecimento das Gerais, então já por volta de 1720, a Bahia não tinha como competir com o Rio de Janeiro. Em documento datado de 1724, d. Lourenço de Almeida, então governador da capitania mineira, deu conta de que Sebastião Barbosa Prado arrematou o contrato do caminho da Bahia, que estava arrematado a 92:160\$000, ${ }^{59}$ por 153:600\$000.$^{60}$ Por volta de 1729, o mesmo governador deu conta de que, em 1723, o contrato dos caminhos Novo e Velho, que estava arrematado a 122:880\$000, o foi por 159:744\$000. ${ }^{61}$ A essa altura, a predominância da capitania do Rio de Janeiro sobre as capitanias da Bahia e de Pernambuco já não causa estranheza alguma.

O que se observa é algo intrigante. No momento em que as capitanias da Bahia e de Pernambuco figuram como os principais portos negreiros da colônia, a capitania do Rio de Janeiro recebe o maior número de procurações provenientes da comarca mineira detentora do maior número de escravos até meados do século XVIII. ${ }^{62}$ E mais, o valor do contrato das entradas provenientes dos caminhos Novo e Velho já vinha superando os valores dos contratos do caminho do Sertão da Bahia desde 1720. Tais dados indicam, em primeiro lugar, que não se pode desconsiderar o peso do mercado de abastecimento de

\footnotetext{
${ }^{57}$ A média fluminense foi retirada a partir de RIBEIRO, Alexandre Vieira. O tráfico atlântico de escravos..., op. cit., p. 127-131. O período compreendido entre 1725 e 1748 deve-se em função dos anos escolhidos por Sampaio para a análise do valor dos contratos dos direitos dos escravos que vão para as Minas. Os anos escolhidos foram: 1725, 1729, 1732, 1740, 1745 e 1748. SAMPAIO, Antônio Carlos. Na encruzilhada do império..., op. cit., p. 150.

${ }^{58}$ SAMPAIO, Antônio Carlos. Na encruzilhada do império..., op. cit., p. 149.

${ }^{59} \mathrm{O}$ valor do contrato foi dado em arrobas. Converti à razão de $1 \$ 500 /$ oitava em função de ter sido esta a razão utilizada por Antônio Carlos Jucá na conversão por ele empreendida.

${ }^{60} \mathrm{AHU}, \mathrm{MG}, \mathrm{cx} .5$, doc. 83 .

${ }^{61} \mathrm{AHU}, \mathrm{MG}, \mathrm{cx} .14$, doc. 67.

${ }^{62}$ Acerca do mapa da capitação ver CARRARA, op. cit., p. 327.
} 
secos e molhados dirigido para a região das Minas. Segundo, tendo em conta a forte concentração da empresa traficante, não havia a necessidade de se nomear vários procuradores envolvidos em tais atividades. Contudo, constituindo-se o tráfico como o principal instrumento de acumulação interna à colônia, e tendo em conta o alto preço pago pelo escravo em Minas quando comparado com o preço do mesmo no Rio e na Bahia, creio que a principal explicação para os números acima apresentados reside na própria geografia do tráfico, quer na colônia, quer na África.

De acordo com o anteriormente demonstrado, tanto os traficantes fluminenses não limitavam seu raio de ação na região da África Centro-Ocidental, como seus congêneres baianos e pernambucanos não o faziam na África Ocidental. Mais importante, havia uma rota, bastante ativa, na qual traficantes e agentes mercantis residentes na Bahia e em Pernambuco enviavam seus carregamentos de africanos para o Rio de Janeiro e, de lá, para a capitania de Minas. Motivos para a existência de tal rota não faltavam: 1) em 1699, a coroa proibiu o uso do caminho do Sertão da Bahia - o que necessariamente não impediu a remessa de escravos por tal caminho; 2) os traficantes baianos e pernambucanos podiam tal qual o governador de Angola, Luiz César de Menezes - estar atraídos pelos melhores preços alcançados pelos escravos no Rio de Janeiro; 3) os próprios traficantes fluminenses, buscando uma inserção na Costa da Mina, mantinham agentes mercantis na Bahia para adquirir tabaco. Enfim, a rota Bahia - Rio de Janeiro, em perfeita sintonia com os "ventos negreiros" do Atlântico Sul, ${ }^{63}$ provia a capitania fluminense com parte dos escravos que para a capitania baiana rumavam, e contribuía, de forma contundente, para a formação e consolidação do "espaço econômico" anteriormente estabelecido. Não se deve perder de vista: no imposto de entrada em Minas também o escravo era taxado. Nesse sentido, a superação do valor dos contratos dos caminhos Novo e Velho em relação ao contrato do caminho do Sertão da Bahia e Pernambuco ganha nova dimensão.

Conforme dito no início deste artigo, não é interesse meu estabelecer hierarquias entre tal e tal praça no abastecimento da região de Minas. O que pretendi com a exposição acima foi realçar o dinamismo proveniente do "espaço econômico" costurado com linhas douradas nas rotas do tráfico negreiro. Nesse sentido, entendo não ser possível compreender os circuitos mercantis mineiros

\footnotetext{
${ }^{63}$ ALENCASTRO, Luiz Felipe de. O trato dos viventes: formação do Brasil no Atlântico Sul. São Paulo: Companhia das Letras, 2000, p. 57-63.
} 
sem compreender os circuitos mercantis fluminenses e baianos os quais, por sua vez, não se tornam inteligíveis sem compreender os circuitos africanos e a carreira da Índia. Sem mencionar a importância das chegadas e partidas das frotas do e para o reino. Em conclusão, a seguir darei vez à análise tanto dos indivíduos residentes no termo de Vila do Carmo que estavam a passar procurações para a capitania da Bahia, de Pernambuco e do Rio de Janeiro, quanto dos traficantes baianos mais nomeados nas procurações passadas no termo de Vila do Carmo. Arrisco dizer que creio não causará espanto o fato de, por via de regra, sempre se nomearem procuradores tanto para a cidade da Bahia como para a do Rio de Janeiro.

\section{0 caso da cidade da Bahia}

Conforme visto acima, o tráfico atlântico de escravos e o ouro em muito contribuíram para a interação do "espaço econômico" apresentado. As descobertas auríferas promoveram um rearranjo nos circuitos econômicos vigentes, até então se constituindo o tráfico negreiro em uma das molas angulares de tal processo. No alvorecer do século XVIII, intentando estabelecer um controle sobre esse processo, a Coroa buscou limitar o número de escravos enviados de Angola e da Bahia para o Rio de Janeiro, objetivando, com isso, resguardar capitanias como a de São Paulo. Em 9 de agosto de 1706, o Conselho Ultramarino deu conta ao rei d. João V sobre o que informou o governador e capitão-geral do Brasil, Luis César de Menezes. Acerca do alvará régio de 20 de janeiro de 1701, pelo qual "dos negros que de Angola forem para o Rio de Janeiro se tirem duzentos todos os anos para os paulistas", escreveu Luis César:

publicado este alvará achou meu antecessor, D. Rodrigo da Costa, que para ser observado era necessário acrescentar-lhe mais circunstâncias e penas que foram a de ser queimada a embarcação que dessa cidade [Bahia] e seus distritos levasse negros para o Rio de Janeiro e mais capitanias do sul sem ordem deste governo e o mestre da embarcação degredado por seis anos para Angola e o senhor da embarcação pagaria da cadeia desta cidade 600 mil réis para as obras públicas dela, que de tudo mandou deitar um bando que V. Majestade foi servido aprovar. ${ }^{64}$

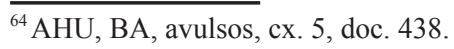


Conforme o governador-geral, em 1703 "se fez 3 tomadias de negros". Em 1704 e 1705, uma sumaca por ano. O motivo do número pequeno de tomadias é justificado:

se livrão de levar os negros em sumacas que estas, como são embarcações grandes e de registro, não saem para fora sem despacho e exame, que lhes fazem os oficiais de justiça; e os levam em barcos pequenos, que saem e entram sem registro quando querem, assim desta Bahia, como de seu dilatado Recôncavo, sem temor de serem tomadas, as horas que lhe parece, levando quantos querem, como se não foram proibidos termos, em que fica sem remédio, vulnerado o dito bando por V. Majestade aprovado. ${ }^{65}$

Do acima exposto, interessa realçar a comunhão entre os circuitos negreiros e os circuitos do ouro os quais, conforme já apontado, concorreram para o estabelecimento de estreitos laços entre as regiões da Bahia, Minas Gerais e Rio de Janeiro. Uma das peças-chave desse processo, os traficantes de escravos desempenharam o papel primeiro nesses circuitos, qual seja: adquirir escravos na costa africana e remetê-los à capitania mineira, direta ou indiretamente. No que respeita aos traficantes baianos, por vezes outorgantes sediados em Minas os nomearam para seus procuradores na cidade da Bahia. Vejamos a tabela 4.

Em primeiro lugar, as ressalvas. Para os períodos compreendidos entre 17001710 e 1731-1740, não adicionei a coluna A. O motivo para tanto é bastante simples: o primeiro livro de nota presente no Arquivo da Casa Setecentista de Mariana data de 1710, o que inviabiliza o acesso a procurações passadas antes de tal ano. Evidentemente, isso não significa a inexistência de ligações entre residentes em Minas e traficantes baianos. Como ainda não realizei a pesquisa para além do ano de 1730, logicamente não trabalhei com nenhuma procuração pós-30. Daí não haver a coluna A para esse período. Entretanto, no que respeita às viagens negreiras empreendidas pelos procuradores traficantes, assim como ao número de escravos por eles desembarcados, optei por considerar os pré-1710 e pós-1730, pois a admissão desses anos na análise concorre para uma melhor compreensão, não apenas da inserção dos traficantes no comércio negreiro, mas também das estratégias dos outorgantes mineiros para nomear seus procuradores.

${ }^{65}$ Idem. 


\begin{tabular}{|c|c|c|c|c|c|c|c|c|c|c|}
\hline \multicolumn{11}{|c|}{$\begin{array}{c}\text { Tabela } 4 \\
\text { Participação dos traficantes baianos nas procurações passadas no termo de Vila do Carmo, } 1711 \text { - } 1730\end{array}$} \\
\hline \multirow{2}{*}{ Traficantes } & \multicolumn{2}{|c|}{$1700-1710$} & \multicolumn{3}{|c|}{ 1711-1720 } & \multicolumn{3}{|c|}{ 1721-1730 } & \multicolumn{2}{|c|}{ 1731-1740 } \\
\hline & B & $\mathrm{C}$ & A & B & $\mathrm{C}$ & $\mathbf{A}$ & B & C & B & C \\
\hline Antônio Correa Seixas & & & & & & 1 & 1 & 390 & 8 & 2.822 \\
\hline Antônio dos Santos & & & & & & 1 & 1 & 307 & 2 & 796 \\
\hline $\begin{array}{l}\text { Antônio Gonçalves da } \\
\text { Rocha }\end{array}$ & 1 & 307 & & & & 2 & & & & \\
\hline $\begin{array}{l}\text { Domingos da Costa } \\
\text { Guimarães }\end{array}$ & 3 & 921 & 3 & 1 & 307 & & & & & \\
\hline $\begin{array}{l}\text { Domingos de Azeredo } \\
\text { Coutinho }\end{array}$ & & & 3 & 1 & 307 & 4 & & & & \\
\hline Félix de Lemos Coimbra & & & & & & 1 & 11 & 3.062 & & \\
\hline Francisco de Barros Rego & & & & & & 2 & & & 3 & 1.180 \\
\hline $\begin{array}{l}\text { Francisco Lopes Vilas } \\
\text { Boas }\end{array}$ & & & & 1 & 307 & 2 & & & & \\
\hline Francisco Veloso & & & & 1 & 307 & 1 & & & & \\
\hline $\begin{array}{l}\text { Francisco Xavier da } \\
\text { Silveira }\end{array}$ & & & & & & 1 & 1 & 307 & 7 & 2.564 \\
\hline Gonçalo de Brito Barros & 2 & 614 & 1 & & & 1 & & & & \\
\hline João Ferreira de Sousa & 1 & 307 & & 27 & 8.306 & 8 & 21 & 6.763 & 9 & 3.657 \\
\hline João Lopes Fiúza & 1 & 307 & 1 & & & & & & & \\
\hline $\begin{array}{l}\text { João Pereira de } \\
\text { Vasconcelos }\end{array}$ & & & 1 & & & & 1 & 307 & & \\
\hline José de Araújo Rocha & 1 & 307 & & 2 & 614 & 1 & & & & \\
\hline $\begin{array}{l}\text { Lourenço da Costa } \\
\text { Ferreira }\end{array}$ & 1 & 307 & 1 & & & & & & & \\
\hline $\begin{array}{l}\text { Manoel da Costa de } \\
\text { Oliveira }\end{array}$ & & & 1 & & & & 1 & 307 & 5 & 1.989 \\
\hline $\begin{array}{l}\text { Manoel Fernandes da } \\
\text { Costa }\end{array}$ & & & 1 & & & 6 & 3 & 921 & 9 & 3.837 \\
\hline Manoel Gomes Lisboa & 1 & 307 & 4 & 2 & 614 & & & & & \\
\hline $\begin{array}{l}\text { Manoel Gonçalves } \\
\text { Machado }\end{array}$ & & & & & & 3 & 2 & 705 & 3 & 949 \\
\hline Manoel Gonçalves Viana & 5 & 1.628 & 2 & 23 & 7.029 & 2 & 20 & 6.547 & 1 & 219 \\
\hline Manoel Nunes Pereira & & & & 1 & 273 & 1 & 2 & 614 & 1 & 277 \\
\hline $\begin{array}{l}\text { Manoel Ramos Aires } \\
\text { Leme }\end{array}$ & 8 & 2.457 & 2 & & & & & & & \\
\hline $\begin{array}{l}\text { Pedro da Silva de } \\
\text { Macedo }\end{array}$ & & & & & & 2 & 2 & 614 & 2 & 955 \\
\hline $\begin{array}{l}\text { Silvestre Ramos } \\
\text { Bandeira }\end{array}$ & & & & & & 1 & & & 4 & 1.513 \\
\hline Simão Álvares Santos & 1 & 307 & & & & 1 & & & & \\
\hline Total & 25 & 7.769 & 17 & 58 & 17.757 & 35 & 66 & 20.844 & 54 & 20.758 \\
\hline \multicolumn{11}{|c|}{ Fonte: ACSM, LN 1-15 e 25-35, EPB e TSTD. } \\
\hline $\begin{array}{ll}\text { Legenda: } & \mathbf{A}-\mathrm{n}^{\circ} . \text { de nomea } \\
& \mathbf{C}-\text { total de escra } \\
\end{array}$ & & $\begin{array}{l}\text { urador } \\
\text { cado nc }\end{array}$ & & & via & & & & & \\
\hline
\end{tabular}


Pela tabela 4, mormente se emitia procuração para um traficante, ou antes, ou ao longo de suas atividades no trato. Nos nove casos em que a procuração fez-se após o término da atuação do procurador no comércio negreiro - excetuei Domingos de Azevedo Coutinho -, observa-se tratarem-se, em sete ocorrências, de traficantes especuladores, aqueles que participaram em apenas uma ou duas viagens - provavelmente movidos pela boa conjuntura proveniente das descobertas do ouro. ${ }^{66}$ Das 203 viagens empreendidas no período, 124 compreenderam-se entre 1711 e 1730. No decênio seguinte, embora o número de idas ao continente africano tenha diminuído em relação ao período anterior, o número de desembarques teve um aumento proporcional. Tais números revelam serem estes alguns dos traficantes mais atuantes no período abordado. Esse fato pode ser confirmado tendo em conta que, dos vinte e cinco nomeados, sete eram traficantes especuladores, ou seja, responsáveis por um número menor de escravos desembarcado no período. Ainda assim, esses homens responderam por 22,93\% dos 292.670 escravos desembarcados na Bahia entre 1700 e $1740 .{ }^{67}$ A conclusão torna-se ainda mais contundente quando observamos em detalhe relação entre o total de escravos desembarcados pelos traficantes acima com o total geral. A tabela 5 aborda a questão.

\begin{tabular}{|c|c|c|c|c|}
\hline \multicolumn{5}{|c|}{ 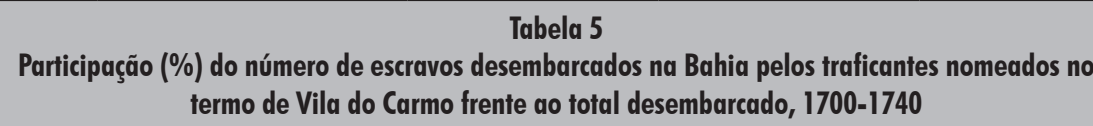 } \\
\hline & $1700-1710$ & $1711-1720$ & $1721-1730$ & $1731-1740$ \\
\hline $\mathbf{A}$ & 81.010 & 84.712 & 67.263 & 59.685 \\
\hline $\mathbf{B}$ & 7.769 & 17.757 & 20.844 & 20.758 \\
\hline $\mathbf{C}$ & 9,59 & 20,96 & 30,98 & 34,77 \\
\hline \multicolumn{5}{|c|}{ Fonte: Tabela 4 e TSTD. } \\
\hline Legenda: & $\begin{array}{l}\text { A - total de escravos no } \\
\text { C - porcentagem de B }\end{array}$ & $l^{\circ}$. de escravos d & pelos procurador & \\
\hline
\end{tabular}

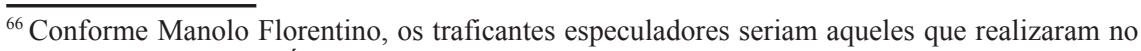
máximo duas viagens à África. Nas palavras do autor: “como era de se esperar, em termos gerais a participação destes comerciantes não especializados e aventureiros se pautava pela intensificação dos investimentos em momentos de maior demanda, e, portanto, de maior cotação dos escravos no mercado brasileiro. Era quando eles assumiam o papel estrutural antes mencionado, que os tornava imprescindíveis ao bom funcionamento das importações de mão-de-obra e da própria economia escravista". FLORENTINO, Manolo. Em costas negras, op. cit., p. 153.

${ }^{67}$ TSTD. Alexandre Vieira Ribeiro apresenta números inferiores acerca do total de escravos desembarcados na Bahia. Segundo o autor a soma daria 217.970, o que aumentaria a porcentagem de 22,93 para 30,79. Cf. RIBEIRO, Alexandre Vieira. O tráfico atlântico de escravos e a praça mercantil de Salvador, op. cit., p. 127-131. Contudo, preferi manter os números do TSTD, pois identifiquei e retirei as informações sobre os traficantes presentes na tabela 5 a partir do banco de dados TSTD.
} 
A partir da tabela 5, observa-se um contínuo aumento na participação dos traficantes nomeados frente ao total de escravos desembarcados. A tabela 6 ajuda a compreender esse fenômeno. A explicação reside, provavelmente, no aumento das escrituras passadas a esses comerciantes, signo quer do aumento das atividades extrativas e agropecuárias na capitania mineira, quer da elevação do preço do escravo no termo de Vila do Carmo. O acréscimo da freqüência dos traficantes nas escrituras está em perfeita conformidade com o movimento geral das mesmas. De acordo com a tabela 6, a partir do final da década de 1720 , ocorre tanto um aumento percentual nas escrituras passadas para a cidade da Bahia, como nos procuradores nomeados para a localidade.

\begin{tabular}{|l|c|c|c|c|}
\hline \multicolumn{5}{|c|}{$\begin{array}{c}\text { Tabela 6 } \\
\text { Movimento geral das procurações e dos procuradores para a cidade da Bahia - 1711- } \\
\text { 1730 }\end{array}$} \\
\hline \multicolumn{1}{|c|}{ Procurações } & Índice & Procuradores & Índice \\
\hline $\mathbf{1 7 1 1}$ & 3 & 18 & 17 & 22 \\
\hline $\mathbf{1 7 1 2}$ & 8 & 50 & 24 & 32 \\
\hline $\mathbf{1 7 1 3}$ & 18 & 112 & 82 & 109 \\
\hline $\mathbf{1 7 1 4}$ & 13 & 81 & 47 & 62 \\
\hline $\mathbf{1 7 1 5}$ & 11 & 68 & 36 & 48 \\
\hline $\mathbf{1 7 1 6}$ & 6 & 37 & 25 & 33 \\
\hline $\mathbf{1 7 1 7}$ & 19 & 118 & 85 & 113 \\
\hline $\mathbf{1 7 1 8}$ & 16 & 100 & 62 & 82 \\
\hline $\mathbf{1 7 1 9}$ & 25 & 156 & 112 & 149 \\
\hline $\mathbf{1 7 2 0}$ & 21 & 131 & 121 & 161 \\
\hline $\mathbf{1 7 2 6}$ & 20 & 125 & 98 & 130 \\
\hline $\mathbf{1 7 2 7}$ & 18 & 112 & 89 & 118 \\
\hline $\mathbf{1 7 2 8}$ & 34 & 212 & 133 & 177 \\
\hline $\mathbf{1 7 2 9}$ & 18 & 112 & 79 & 105 \\
\hline $\mathbf{1 7 3 0}$ & 17 & 106 & 122 & 162 \\
\hline Fonte: ACSM, LN 1-15 e $25-35$, EPB. & & & \\
\hline & & & & \\
\hline
\end{tabular}

Dentre os traficantes de escravos nomeados por procuradores no termo de Vila do Carmo para a cidade da Bahia, Manoel Gonçalves Viana ocupou destacada posição. Entre 1701 e 1740, Manoel Gonçalves foi responsável por 49 viagens negreiras, sendo quatro delas como sócio secundário de outros traficantes. Nesse período, desembarcou no porto de Salvador nada menos do 
que 15.423 escravos. Sua atuação centralizou-se entre os anos de 1710 e 1730 , período no qual realizou 43 viagens abrangendo 13.576 escravos ${ }^{68}$ Coincidência ou não, todas as quatros vezes em que foi nomeado procurador ocorreram no seu período de maior atuação no tráfico Atlântico de escravos.

Em 20 de junho de 1719, o capitão Manoel Mendes de Almeida nomeou seis procuradores para a comarca de Vila Rica, quatro para a comarca do Rio das Mortes, três para a cidade de São Paulo, dois para a Vila de Santos, quatro para a cidade do Rio de Janeiro - dois deles homens de negócio, dentre os quais Paulo Carvalho da Silva (negociantes da família Almeida Jordão, umas das mais poderosas residente na capitania fluminense $)^{69}$-, três para a cidade da Bahia - nos quais incluíam-se Manoel Gonçalves Viana e José Gonçalves Viana (provavelmente parente de Manoel) -, um para a cidade de Olinda e nove para o reino - três para a cidade do Porto e seis para a cidade de Lisboa. ${ }^{70}$ Quase um ano após ter passado a escritura acima, em 11 de maio de 1720, o capitão Manoel Mendes de Almeida vendeu, no termo de Vila do Carmo, 16 escravos pela quantia de 6:6120\$000, a serem pagos em dois anos - cerca de pouco mais de $400 \$ 000$ por escravo. ${ }^{71}$ Se tais escravos foram fruto de transações realizadas, especificamente, entre Manoel Mendes e Manoel Gonçalves, nada posso afirmar. Contudo, entendo ser este um exemplo dos circuitos mercantis em que o tráfico e o ouro das minas interligavam-se.

Em 22 de junho de 1719, o capitão João Carneiro Pereira nomeou oito procuradores para a capitania de Minas Gerais, três para a cidade do Rio de Janeiro - sendo um homem de negócio e outro senhor de engenho e membro da nobreza da terra- ${ }^{72}$ seis para a cidade da Bahia e dez para o reino - cinco para a cidade de Lisboa e cinco para a Vila de Sá. ${ }^{73}$ Manoel Gonçalves Viana também foi representante dos interesses do sargento-mor Bento Ferraz Lima na cidade da Bahia. Em 19 de janeiro de 1726, Bento Ferraz nomeou quinze

\footnotetext{
${ }^{68}$ Banco de dados TSTD.

${ }^{69}$ Acerca de a família Almeida Jordão ver SAMPAIO, Antônio Carlos Jucá. A família Almeida Jordão na formação da comunidade mercantil carioca (c.1690 - c.1750). In: Anais do VI Congresso de História Econômica e $7^{a}$ Conferência Internacional de História de Empresas. Conservatória, 2005. ${ }^{70}$ ACSM, LN 09, EPB, 20/06/1719.

${ }^{71}$ ACSM, LN 13, ECV, 11/05/1720.

${ }^{72}$ Acerca da noção de "nobreza da terra", ver FRAGOSO, João. A nobreza da República: notas sobre a formação da primeira elite senhorial do Rio de Janeiro (séculos XVI e XVII). In: Topoí: Revista de História. Rio de Janeiro, vol. 1, 2000, p. 45-122.

${ }^{73}$ ACSM, LN 09, EPB, 22/06/1719.
} 
procuradores para a comarca de Vila Rica, quatro para a cidade do Rio de Janeiro, quatro para a Vila de Santos, dois para a cidade de São Paulo, sete para a cidade da Bahia, quatro para a capitania de Pernambuco e cinco para o reino - quatro para a cidade de Lisboa e um para o distrito de Viana do Castelo, província do Minho. ${ }^{74}$ Senhor de engenho e minerador, o sargento-mor Bento Ferraz Lima integrou o grupo dos grandes potentados de Minas nas primeiras décadas do século XVIII. ${ }^{75}$

Os três exemplos acima demarcam a potencialidade do raio de ação dentro do qual atuavam circuitos como o do tráfico atlântico de escravos e o do ouro. Sem desconsiderar o mercado de abastecimento proveniente da capitania de São Paulo - que de qualquer forma passava pela capitania fluminense -, nem possíveis negócios (mercantis ou não) a serem realizados no reino, o "espaço econômico" formado a partir das descobertas auríferas, o qual interligava as três principais capitanias do Brasil naquele momento (Bahia, Minas Gerais e Rio de Janeiro), traz à baila a interação, direta ou indireta, entre traficantes residentes na Bahia, poderosos senhores de engenho e mineradores atuantes em Minas Gerais e grandes homens de negócio do Rio de Janeiro.

Das quatro procurações em que Manoel Gonçalves Viana fora nomeado procurador, a única que foge ao padrão acima foi passada por Constantino da Mota, em 6 de setembro de 1728. Por ela, foram nomeados apenas quatro procuradores, e todos eles para a cidade da Bahia. Por outro lado, trata-se da única procuração em que dois traficantes foram nomeados. Além de Manoel Gonçalves, Constantino da Mota nomeou seu procurador na cidade da Bahia Antônio Correa Seixas, ${ }^{76}$ responsável por nove viagens à costa africana entre 1721 e 1740 , tendo desembarcado na Bahia cerca de 3.200 escravos. $^{77}$

Aliás, é exatamente na conformidade das procurações onde reside um dos segredos para se desvendar as formas de atuação desses homens dentro do "espaço econômico" aqui sugerido. A título de exemplo, observando a procuração passada por João Carneiro na qual Manoel Gonçalves Viana surge como procurador, percebe-se a nomeação de um senhor de engenho e membro

\footnotetext{
${ }^{74}$ ACSM, LN 26, EPB, 19/01/1726.

${ }^{75}$ Ver KELMER MATHIAS, Carlos Leonardo. Jogos de interesses..., op. cit., p. 111; ANASTASIA, Carla. Vassalos rebeldes: violência coletiva nas Minas na primeira metade do século XVIII. Belo Horizonte: C/Arte, 1998, p. 100-104.

${ }^{76}$ ACSM, LN 31, EPB, 06/09/1728.

${ }^{77}$ Banco de dados TSTD.
} 
da nobreza da terra no Rio de Janeiro. Trata-se do capitão-mor Manoel Pereira Ramos. Entre atividades de compra, venda e crédito realizadas entre 1711 e 1720 - excetuando apenas uma escritura de dívida, obrigação e hipoteca passada em 11 de julho de 1727 -, Manoel Pereira foi responsável pelo giro, no termo de Vila do Carmo, de 87:519\$859, ${ }^{78}$ quantia a qual o transformava no segundo maior agente mercantil do período compreendido entre 1711 e 1730 (salvo os anos de 1721 até 1725$)$.

Das onze escrituras de procuração em que aparece ora como outorgante, ora como procurador, em nenhuma delas Manoel Pereira nomeia ou é nomeado para as capitanias da Bahia ou Pernambuco. Porém, ao analisar os procuradores nomeados por Manoel Pereira para o termo de Vila do Carmo com os indivíduos nomeados pelos procuradores de Manoel Pereira, ganha-se uma nova dimensão das ligações indiretas entre Manoel Pereira e a capitania baiana.

Em 2 de fevereiro de 1719, o capitão-mor Manoel Pereira Ramos nomeou, entre outros procuradores, o mestre-de-campo Manoel de Queirós Monteiro - poderoso potentado em Minas, membro da rede de Manoel Nunes Viana, arrematante de contrato e sócio do sargento-mor Luis Tenório de Molina ${ }^{79}$ (anteriormente citado como sócio de uma viagem negreira em 1733) - e Luis da Silva. ${ }^{80}$ Este último mantinha cinco procuradores na cidade da Bahia e dois na Vila da Cachoeira, todos nomeados em 1717. ${ }^{11} \mathrm{O}$ mestre-de-campo Manoel de Queirós conservava, por sua vez, dezesseis procuradores na cidade da Bahia, sendo um deles traficante de escravos, um coronel, um sargento-mor, quatro capitães, três "solicitadores de causas", três doutores, um padre e um desembargador da Relação da Bahia. ${ }^{82}$ Logicamente, não posso afirmar estarem os procuradores de Manoel de Queirós ou de Luis da Silva a serviço do capitão-mor Manoel Pereira Ramos. Por outro lado, negar completamente tal possibilidade me parece tão absurdo quanto afirmá-la com veemência.

Manoel Fernandes da Costa, o terceiro traficante nomeado no termo de Vila do Carmo que mais empreendeu viagens negreiras, foi também o segundo mais

\footnotetext{
${ }^{78}$ ACSM, LN 1-15 e 25-35.

${ }^{79}$ Acerca do mestre-de-campo Manoel de Queirós ver KELMER MATHIAS, Carlos Leonardo. Jogos de interesses..., op. cit., e CAMPOS, op. cit.

${ }^{80}$ ACSM, LN 10, EPB, 02/02/1719.

${ }^{81}$ ACSM, LN 07, EPB, 30/08/1717.

${ }^{82}$ ACSM, LN 05, EPB, 16/02/1717; LN 10, EPB, 05/04/1719; LN 11, EPB, 10/12/1719; LN 26, EPB, 26/02/1726.
} 
vezes nomeado, sete no total. Responsável por doze viagens entre 1721 e 1740 - sendo nove delas entre 1731 e 1740 -, e pelo desembarque, em Salvador, de cerca de 4.700 escravos, ${ }^{83}$ Manoel Fernandes realizou sua primeira travessia atlântica em 1726, exatamente o ano a partir do qual recebeu o grosso de suas nomeações como procurador. A única a escapar de tal perfil foi a procuração passada pelo capitão João da Costa Ferreira, quem, em 27 de agosto de 1718, nomeou dez procuradores para a comarca de Vila Rica, seis para a cidade do Rio de Janeiro - sendo um homem de negócio, um mercador, dois familiares do Santo Ofício, um senhor de engenho e um membro da nobreza da terra -, quatro para a cidade da Bahia e doze para o reino - seis para a cidade de Lisboa, cinco para a cidade do Porto e um para a Vila de Viana, província do Minho. ${ }^{84}$

Dentre os demais outorgantes, em 29 de janeiro de 1726, o capitão e senhor de engenho Salvador da Cunha de Carvalho nomeou treze procuradores para a comarca de Vila Rica, cinco para a cidade da Bahia, dois para a cidade do Rio de Janeiro e um para a Vila de Santos, o sargento-mor Torquato Teixeira de Carvalho. ${ }^{85} \mathrm{O}$ sargento-mor Torquato Teixeira de Carvalho foi homem poderoso no alvorecer das Minas. Dentre as várias cartas patentes a ele passadas e os postos ocupados na governança, em 1714 recebeu o comando da fortaleza de Ipanema, na Vila de Santos. ${ }^{86}$ Entre 1711 e 1720, movimentou, através de escrituras de compra e venda e de crédito, cerca de quarenta contos de réis no termo de Vila do Carmo, ${ }^{87}$ dos quais quinze contos referiam-se a uma venda de um engenho com terras minerais e 37 escravos ao próprio capitão Salvador da Cunha de Carvalho. ${ }^{88}$

Em 6 de junho de 1726, Manoel Fernandes da Costa foi novamente nomeado procurador na cidade da Bahia, desta feita por José Rodrigues Lima que nomeou procuradores para as comarcas de Vila Rica e Rio das Velhas, para as capitanias da Bahia, do Rio de Janeiro e de São Paulo. ${ }^{89}$ Os demais outorgantes os quais nomearam Manoel Fernandes por procurador foram: Francisco

\footnotetext{
${ }^{83}$ Banco de dados TSTD.

${ }^{84}$ ACSM, LN 08, EPB, 27/09/1718.

${ }^{85}$ ACSM, LN 26, EPB, 29/01/1726.

${ }^{86}$ KELMER MATHIAS, Carlos Leonardo. Jogos de interesses..., op. cit., p. 50-51.

${ }^{87}$ ACSM, LN 1-15.

${ }^{88}$ ACSM, LN 13, ECV, 20/09/1720. Ao que parece, esta foi a última transação realizada por Torquato Teixeira no termo de Vila do Carmo, haja vista que a partir de 1726 ele viria a ser nomeado por procurador em oito ocasiões, todas elas para a Vila de Santos. ACSM, LN 26, 28,31 e 33, EPB. ${ }^{89}$ ACSM, LN 26, EPB, 06/06/1726.
} 
Rodrigues Filgueiras, ${ }^{90}$ Matias Lopes da Silveira, ${ }^{91}$ José Gomes Ferreira $^{92}$ - os dois últimos também nomearam homens de negócio para o Rio de Janeiro -, e o mestre-de-campo Francisco Ferreira de Sá. ${ }^{93}$

Francisco Ferreira de Sá revelou-se dono da maior fortuna inventariada no termo de Vila do Carmo entre 1713 e 1756, com um monte-mor no valor de 56:990\$235. Dentre seus bens constavam metais preciosos e dinheiro, bens móveis, 20 porcos, 13 cavalos, várias moradas de casas, um moinho de moer milho, um sítio de agricultura e uma roda de minerar. Entre suas dívidas, 24 passivas e 49 ativas, distribuídas pelas capitanias de Minas e do Rio de Janeiro. Por fim, era senhor de 124 escravos, o que o tornava o dono do segundo maior plantel inventariado. ${ }^{94}$ Ao longo de sua vida, passou quatro procurações, nomeando um total de sessenta e nove procuradores, assim distribuídos: vinte e quatro para a comarca de Vila Rica, cinco para a comarca do Rio das Velhas, três para a comarca do Serro do Frio, onze para a cidade de São Paulo - sendo um deles o já citado capitão Manoel Mendes de Almeida -, quinze para a cidade da Bahia - dentre eles o sargento-mor Luis Tenório de Molina - e onze para a cidade do Rio de Janeiro - sendo dois homens de negócio, um senhor de engenho e membro da nobreza da terra, um familiar do Santo Ofício e Antônio Rodrigues Souto, ${ }^{95}$ para quem devia $548 \$ 590 .{ }^{96}$

Assim como Manoel Gonçalves Viana, Manoel Fernandes da Costa esteve às voltas com membros pertencentes às elites social e econômica do termo de Vila do Carmo. Por sua vez, tais membros não restringiram sua ligação aos traficantes baianos. Conforme anteriormente demonstrado, esses sujeitos se relacionavam com homens de negócio, senhores de engenho e familiares do Santo Ofício residentes na praça fluminense. Assim sendo, através de suas cadeias de nomeações de procuradores, os potentados sediados na capitania do ouro acabavam por interligar, direta ou indiretamente, os traficantes baianos aos homens de negócio e senhores do engenho no Rio de Janeiro. Logicamente, com isso não pretendo excluir a ligação direta entre esses dois grupos. Por

\footnotetext{
${ }^{90}$ ACSM, LN 26, EPB, 05/09/1726.

${ }^{91}$ ACSM, LN 29, EPB, 15/10/1727.

${ }^{92}$ ACSM, LN 29, EPB, 01/04/1728.

${ }^{93}$ ACSM, LN 34, EPB, 22/10/1730.

${ }^{94}$ ACSM, Inventário post-mortem, $1^{\text {o }}$ of., cód. 87, auto 1842.

${ }^{95}$ ACSM, LN 03, EPB, 11/1713; LN 30, EPB, 12/1728; LN 34, EPB, 12/09/1730 e LN 34, EPB, 22/10/1730.

${ }^{96}$ ACSM, IPM, $1^{\text {o }}$ of., cód. 87, auto 1842.
} 
exemplo, entre 1724 e 1730, das dezoito fianças de embarcações concedidas no Rio de Janeiro para o Nordeste, sete o foram por homens de negócio. ${ }^{97}$ Além do mais, já foram discutidas no presente artigo as interações entre as capitanias da Bahia e de Pernambuco com a capitania do Rio de Janeiro por conta do tráfico atlântico de escravos.

Analisando mais atentamente o inventário do mestre-de-campo Francisco Ferreira de Sá, a natureza desse circuito mercantil no qual o tráfico de escravos interagia com o ouro das minas adquire mais complexidade. Dos 124 escravos componentes do plantel, $17,21 \%$ eram crioulos e $82,79 \%$ africanos. Dentre os últimos, 1,98\% provinham da África Oriental, 25,74\% da África CentroOcidental e 72,28\% da África Ocidental. Não obstante a inserção da capitania fluminense na costa ocidental da África, não é possível negar que o plantel de Francisco Ferreira fosse composto, em sua maioria, de escravos provenientes das capitanias da Bahia ou de Pernambuco, fato reforçado tendo em mente sua nomeação como procurador de um traficante do peso de Manoel Fernandes da Costa. Até aqui, nada muito fora do normal.

Contudo, observando a relação dos credores e devedores do mestre-decampo, não há quaisquer dívidas endereçadas às capitanias do Nordeste. Por outro lado, Francisco Ferreira possuía ativos e passivos na capitania fluminense da ordem de mais de 1:100\$000. O que importa não é necessariamente o valor dos créditos, mas o papel desempenhado pelas capitanias da Bahia e do Rio de Janeiro em suas interações nos circuitos econômicos ora estudados. Se por um lado a capitania baiana desempenha o papel de grande abastecedora de escravos para a região das minas entre 1711 e 1730, por outro, a fluminense surge como credora da mesma. ${ }^{98}$ Com isso não pretendo operar reducionismos, mas tãosomente apresentar uma visão mais geral da dinâmica das três capitanias em destaque dentro do "espaço econômico" anteriormente delimitado. Tendo em conta que, pelo menos desde 1720, o Rio de Janeiro já desempenhava a função de principal centro abastecedor de Minas Gerais, tal quadro não é de todo inusitado. O que se observa é a profunda interação havida entre as capitanias da Bahia (Pernambuco) e do Rio de Janeiro promovida pela inserção das mesmas nas rotas do ouro via, fundamentalmente, o tráfico atlântico de escravos.

\footnotetext{
${ }^{97}$ SAMPAIO, Antônio Carlos Jucá. Na encruzilhada do império..., op. cit., p. 240.

${ }^{98}$ Ver KELMER MATHIAS, Carlos Leonardo. A cor negra do ouro..., op. cit., cap. 2.
} 
Acerca dos traficantes nomeados no termo de Vila do Carmo, João Ferreira de Sousa merece uma atenção especial. Entre 1719 e 1730, foi nomeado como procurador em oito ocasiões, sendo sete delas entre 1726 e 1730 . O capitão Domingos Nunes Neto - homem poderoso na capitania mineira em seu alvorecer,$-{ }^{99}$ na mesma escritura em que nomeava João Ferreira de Sousa seu procurador na cidade da Bahia elegia sete procuradores na comarca de Vila Rica, dois na comarca do Rio das Velhas, três para a capitania do Rio de Janeiro - sendo dois homens de negócio -, três para a capitania da Bahia e treze para o reino - quatro para a cidade de Lisboa, três para a cidade do Porto e o restante para a província de Entre Douro e Minho. ${ }^{100}$ Dentre transações de compra e venda e crédito, o capitão Domingos Nunes foi responsável por um volume superior a 35:000\$000, transacionando 105 escravos no termo de Vila do Carmo, comprando e vendendo propriedades que faziam fronteira com o já citado Bento Ferraz Lima. ${ }^{101}$ Francisco Rodrigues de Miranda, além de nomear João Ferreira, também nomeou, em 9 de julho de 1727, dois procuradores para a capitania mineira, três para a capitania fluminense - sendo dois homens de negócio -, três para a capitania baiana - sendo dois traficantes - e quinze para o reino. ${ }^{102}$ Em 26 de fevereiro de 1728, Francisco Rodrigues vendeu um sítio com terras minerais, engenho de pilão, roça e dezessete escravos na freguesia do Sumidouro por 13:000\$000. ${ }^{103}$

Os demais outorgantes a nomear João Ferreira por procurador na cidade da Bahia foram: Domingos Rodrigues Nunes (quatro procuradores para a cidade da Bahia), Antônio de tal (cinco procuradores para a cidade da Bahia, cinco procuradores para a cidade do Rio de Janeiro - sendo um homem de negócio - e oito procuradores para o reino), o alferes Francisco Rodrigues Feliciano (seis procuradores para a comarca de Vila Rica, quatro para a cidade do Rio de Janeiro - sendo dois homens de negócio - e quatro para a cidade da Bahia - sendo dois traficantes de escravos), o doutor Domingos Duarte Pereira (onze para a capitania mineira, três para a capitania baiana e dois para a cidade do Rio de Janeiro), André Barbosa de Barros (cinco para a capitania de Minas e

\footnotetext{
${ }^{99}$ KELMER MATHIAS, Carlos Leonardo. Jogos de interesses..., op. cit., p. 64.

${ }^{100}$ ACSM, LN 10, EPB, 05/06/1719.

${ }^{101}$ ACSM, LN 10, ECV, 24/05/1719; LN 33, ECV, 23/07/1729; LN 37, Escritura de crédito, $13 / 08 / 1727$.

${ }^{102}$ ACSM, LN 28, EPB, 09/07/1727.

${ }^{103}$ ACSM, LN 29, ECV, 26/02/1728.
} 
dois para a da Bahia) e, por último, Manoel de Guerra Brito (dezesseis para a comarca do Rio das Velhas, vinte e dois para a comarca de Vila Rica, seis para a cidade do Rio de Janeiro - sendo dois homens de negócio - quatorze para a cidade da Bahia - sendo dois traficantes - e dezoito para o reino). ${ }^{104}$

Em primeiro lugar, tais nomeações reforçam a comum prática de se nomear sempre um traficante na Bahia e ao menos um homem de negócio no Rio de Janeiro, o que, por seu turno, reafirma a ligação entre ambas as capitanias por intermédio de Minas Gerais confluindo, cada vez mais, para a configuração do "espaço econômico" fruto dos circuitos mercantis do tráfico negreiro e do ouro. Os casos acima contribuem igualmente para a percepção dos estreitos laços entre alguns dos mais destacados potentados mineiros com os traficantes baianos e os homens de negócio residentes na praça fluminense.

Quando se compara João Ferreira de Sousa com os outros dois traficantes acima mencionados - Manoel Gonçalves Viana e Manoel Fernandes da Costa-, o que se percebe é a sua maior atuação no tráfico. Entre 1700 e 1740, João Ferreira respondeu por 50 viagens negreiras - sendo uma como sócio secundário - e pelo desembarque de 19.033 escravos na capitania baiana. ${ }^{105}$ Contudo, há de se ter cuidado no trato com João Ferreira. Em 27 de setembro de 1729, o provedor da Alfândega da cidade da Bahia, Domingos da Costa de Almeida, deu conta ao rei sobre o falecimento do guarda-mor da Alfândega João Ferreira de Sousa, em junho do mesmo ano. ${ }^{106}$ Também obtive notícias de um João Ferreira de Sousa, caixeiro e administrador do contrato dos reais dízimos da Bahia, arrematado por Manoel Martins Leão em 1719. Segundo o documento, caixeiro e arrematante estavam a dever 44:287\$710 para a Fazenda Real. ${ }^{107}$ De qualquer forma, tendo sido o traficante, o guarda-mor ou o caixeiro e administrador do contrato, percebe-se a estratégia dos outorgantes acima de buscarem pessoas igualmente influentes e ocupantes de cargos chaves na governança para serem seus procuradores. Porém, não se pode generalizar. A tabela abaixo avança na questão.

\footnotetext{
${ }_{104}$ ACSM, LN 26, EPB, 30/06/1726; LN 31, EPB, 04/1728; LN 29, EPB, 04/05/1728; LN 31, EPB, 11/08/1728; LN 31, EPB, 30/08/1728; LN 34, EPB, 07//09/1730.

${ }^{105}$ Banco de dados TSTD.

${ }^{106}$ AHU, BA, avulsos, cx. 24, doc. 64.

${ }^{107}$ AHU, BA, avulsos, cx. 23, doc. 2105.
} 


\begin{tabular}{|c|c|c|c|c|c|c|c|}
\hline \multicolumn{8}{|c|}{$\begin{array}{c}\text { Tabela } 7 \\
\text { Ocupação e titulação geral (à exceção dos traficantes) dos procuradores nomeados para a cidade } \\
\text { da Bahia, } 1711-1730\end{array}$} \\
\hline \multicolumn{2}{|c|}{ Militar } & \multicolumn{2}{|c|}{ Especializado } & \multicolumn{2}{|c|}{ Governança } & \multicolumn{2}{|c|}{ Religioso } \\
\hline A & B & A & B & A & B & A & $\mathbf{B}$ \\
\hline 48 & 116 & 62 & 490 & 5 & 23 & 18 & 37 \\
\hline \multicolumn{8}{|c|}{ Fonte: ACSM, LN 1-15 e 25-35, EPB. } \\
\hline Legenda: & $\begin{array}{l}\mathbf{A} \text { - nú } \\
\mathbf{B} \text { - tota }\end{array}$ & $\begin{array}{l}\text { e proct } \\
\text { omead }\end{array}$ & $\begin{array}{l}\text { nomea } \\
\text { upo soci }\end{array}$ & reço & conta & ão do & radores \\
\hline
\end{tabular}

Excetuar os traficantes da tabela acima se justifica não apenas por já terem sido trabalhados, mas, fundamentalmente, por estarem distribuídos entre militares, requerentes de causa e até um desembargador da Relação da Bahia. Nesse sentido, um campo à parte específico para os traficantes acabaria por distorcer o quadro mais geral expresso pela tabela 7. Por ele, percebe-se a predominância exercida por indivíduos doutos, como licenciados, requerentes de causa, doutores e bacharéis. Tendo em conta que os procuradores eram indivíduos responsáveis por representar os interesses do outorgante em toda e qualquer ação civil ou comercial, seria de se esperar a hegemonia de tais homens. No que concerne ao segundo grupo com maior freqüência nas procurações, dos treze traficantes para os quais pude identificar patente ou cargo, oito eram militares, fato que pode ter contribuído para esse grupo ocupar a segunda posição entre as ocupações dos procuradores. De mais a mais, a ocupação de patentes militares entre os indivíduos pertencentes aos mais altos estratos sociais era bastante comum.

A tabela 7 também permite tecer considerações acerca das estratégias empreendidas pelos outorgantes na escolha por seus procuradores. A título de exemplo, os quatro indivíduos mais freqüentes entre os procuradores nomeados para a cidade da Bahia foram: o doutor Francisco Correia Ximenes com setenta e quatro nomeações; Antônio Correia Ximenes, doutor e irmão de Francisco Correia, nomeado em sessenta e sete procurações; José de Araújo Pinto, doutor e feito procurador em cinqüenta e nove ocasiões; e Diogo Fernandes Roxo, requerente de causa nomeado em cinqüenta e uma procurações. Esses quatro indivíduos sozinhos responderam por mais de 51\% das procurações passadas a letrados. $\mathrm{O}$ forte monopólio exercido por eles não pode ser atribuído a uma falta de homens eruditos na cidade da Bahia, haja vista que por lá foram nomeados 
dois bacharéis, nove licenciados, onze requerentes de causa e quarenta doutores. Essa alta concentração nas nomeações dos indivíduos letrados revela que, no momento de se nomear um procurador especializado em assuntos jurídicos das mais diversas naturezas, os outorgantes optavam pelos procuradores mais reconhecidos, pouco arriscando em nomear um sujeito talvez menos influente ou importante na localidade de destino.

Outra conclusão passível de ser aferida a partir da tabela 7 diz respeito à composição das procurações. Habitualmente, nomeavam-se um ou dois letrados facultados a resolverem questões mais gerais de ordem jurídica para, então, nomearem-se procuradores específicos - na maioria das vezes pessoas conhecidas dos outorgantes -, incumbidos de questões específicas. Não é por acaso que, em toda procuração na qual fora nomeado um traficante, também o fora um letrado. Por fim, gostaria de destacar a atuação dos indivíduos integrantes do grupo aqui denominado governança.

Nos postos de governança, incluem-se três cargos, quais sejam: guarda-mor da alfândega, ${ }^{108}$ guarda-mor da Relação da Bahia e desembargador da Relação da Bahia. Sendo o cargo de maior importância entre todos os procuradores nomeados, os desembargadores eram ministros letrados providos pelo rei para atuar nos tribunais superiores - Relação da Bahia, Relação de Goa, Relação do Porto, Casa da Suplicação, Conselho Ultramarino, Mesa da Consciência e Desembargo do Paço. No que concerne à colônia, os desembargadores deviam "tomar conhecimento dos agravos e apelações de decisões de ouvidores, provedores, intendentes, juízes e governadores". Nomeados para dois triênios, deviam fazer visitas às capitanias, sempre em dupla, e "tirar residência dos funcionários régios". Não poderiam tomar afilhados e nem "responder cartas de pretendentes". Sobretudo, somente poderiam ser suspensos de suas funções por ordem régia. ${ }^{109}$ Além de tais atribuições, por vezes os desembargadores

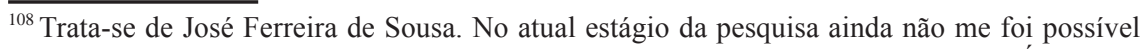
identificar precisamente se era o traficante, o guarda-mor ou o caixeiro-administrador. É bastante provável que o guarda-mor e o caixeiro sejam a mesma pessoa, mas, por hora, prefiro não tecer maiores considerações, além das acima expostas, sobre José Ferreira. Acerca das atribuições de um guarda-mor da alfândega ver SALGADO, Graça (org.). Fiscais e meirinhos: a administração no Brasil colonial. Rio de Janeiro: Nova Fronteira, 1985, p. 163.

${ }^{109}$ CÓDICE Costa Matoso, op. cit., vol. II, p. 91. Sobre a Relação da Bahia, Stuart Schwartz continua a ser referência. SCHWARTZ, Stuart. Burocracia e sociedade no Brasil colonial: a Suprema Corte da Bahia e seus juízes, 1609 - 1751. São Paulo: Perspectiva, 1979, passim.
} 
da Relação da Bahia eram enviados para as regiões africanas com o intuito de conduzir residências e devassas. ${ }^{110}$

Nesses termos, obter um desembargador da Relação da Bahia como procurador facultava ao outorgante $\mathrm{o}$ acesso não apenas à mais alta instância jurídica da colônia, como também a um canal direto com o rei e demais tribunais. Em uma sociedade regida pelos valores e práticas característicos de um "antigo regime nos trópicos", ${ }^{111}$ ter por procurador um desembargador facultava ao outorgante uma posição privilegiada não apenas na defesa de seus interesses, como também poderia lhe garantir privilégios políticos e econômicos frente ao restante da sociedade.

Não por acaso, em apenas quatro procurações nomeou-se um desembargador como procurador - sendo que somente o desembargador Luis de Siqueira da Gama representou os interesses de mais de um outorgante. Os demais desembargadores foram Antônio Sanches Pereira e João Pereira de Vasconcelos. ${ }^{112}$ Essa pouca representatividade do cargo nas procurações aponta para a existência de uma proximidade - para não utilizar a expressão rede -, entre o outorgante e o procurador. $\mathrm{O}$ que não necessariamente ocorria, por exemplo, na nomeação dos irmãos doutores Correia Ximenes. A proximidade entre outorgante e desembargador ainda poderia viabilizar ao primeiro ter um representante seu ocupando os mais altos cargos na administração do império. Segundo Stuart Schwartz, após a passagem pela Relação da Bahia, comumente o magistrado era cotado para assumir postos na Relação do Porto, na Casa da Suplicação ou, após experiência adquirida nesses tribunais, tornar-se membro do Conselho Ultramarino. ${ }^{113}$

Luis de Siqueira Gama, após formar-se em direito canônico e ter atuado como juiz de fora por duas ocasiões, assumiu o posto de desembargador da

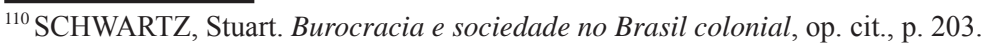

${ }^{111}$ Acerca da noção de "antigo regime nos trópico" ver FRAGOSO, João, BICALHO, Maria F \& GOUVÊA, Maria de Fátima (orgs.). O Antigo Regime nos trópicos: a dinâmica imperial portuguesa (séculos XVI - XVIII). Rio de Janeiro: Civilização Brasileira, 2001.

${ }^{112}$ ACSM, LN 07, EPB, 31/07/1717. Embora o nome de João Pereira de Vasconcelos não consta na lista elaborada por Stuart Schwartz com os desembargadores da Relação da Bahia entre 1609 e 1758, seu nome aparece citado como desembargador em vários requerimentos no Arquivo Histórico Ultramarino da Bahia. Ver, por exemplo, AHU, BA, avulsos, cx. 24, doc. 2201. Acerca da lista elaborada por Schwartz, cf. SCHWARTZ, Stuart. Burocracia e sociedade no Brasil colonial, op. cit., p. 309-325.

${ }^{113}$ SCHWARTZ, Stuart. Burocracia e sociedade no Brasil colonial..., op. cit., p. 245.
} 
Relação da Bahia em 1719. ${ }^{114}$ Em 13 de março de 1719, fora feito procurador na cidade da Bahia pelo capitão-mor Pedro Rodrigues Sanches - o qual, na mesma procuração, nomeou dois homens de negócio para a capitania fluminense - e, em outubro do mesmo ano, pelo capitão José Ferreira Pinto - quem, igualmente, nomeou para a capitania do Rio de Janeiro um familiar do Santo Ofício, um senhor de engenho e membro da nobreza da terra, um arrematante de contrato e dois homens de negócio (um dos quais também era procurador do capitão-mor Pedro Rodrigues Sanches). ${ }^{115}$ Após servir na Relação da Bahia, Luis de Siqueira - que havia se casado, na Vila de Santos, com Catarina Álvares da Cunha -, atuou na Relação do Porto e, posteriormente, na Casa da Suplicação. ${ }^{116}$

Antônio Sanches Pereira, feito desembargador em 1713, era cavaleiro professo da Ordem de Cristo. Após sua passagem pela Relação da Bahia, assumiu um cargo na Casa da Suplicação. ${ }^{117}$ Sua nomeação para procurador ocorreu em 1719. O outorgante foi o já citado mestre-de-campo Manoel de Queirós Monteiro, homem às voltas com traficantes baianos, poderosos mineiros e senhores de engenho do Rio de Janeiro. ${ }^{118}$ Entre escrituras de compra e venda, Manoel de Queirós foi responsável por uma movimentação financeira de mais de 42 contos de réis no termo de Vila do Carmo, transacionando um total de 82 escravos. ${ }^{119} \mathrm{O}$ mestre-de-campo, por sua vez, representou os interesses de vinte e nove pessoas, sendo nomeado procurador para as comarcas de Vila Rica, Rio das Morte e Serro do Frio. Também recebeu uma nomeação para a capitania da Bahia e uma para a capitania de São Paulo. ${ }^{120}$

Dentre os outorgantes de Manoel de Queirós há os já citados: Pedro Rodrigues Sanches, Manoel Pereira Ramos, Luis Tenório de Molina, Torquato Teixeira de Carvalho e Salvador da Cunha de Carvalho. Afora esses, nomes como o sargento-mor Francisco Barreto Bicudo, Guilherme Mainarde da Silva, o sargento-mor Domingos Pinto Magalhães, envolvidos com grandes transações no termo de Vila do Carmo - ou através de escrituras de compra e venda, ou de crédito -, figuraram entre seus outorgantes. Todos às voltas, na

\footnotetext{
${ }^{114}$ Idem, p. 319.

${ }^{115}$ ACSM, LN 09, EPB, 13/03/1719; LN 11, EPB, 10/1719, respectivamente.

${ }^{116}$ SCHWARTZ, Stuart. Burocracia e sociedade no Brasil colonial..., op. cit., p. 306 e p. 319.

${ }^{117}$ Idem, p. 318.

${ }^{118}$ ACSM, LN 10, EPB, 05/04/1719.

${ }^{119}$ ACSM, LN 02, ECV, 02/1712; LN 04, ECV, 24/04/1715; LN 31, ECV, 10/05/1728; LN 33, ECV, 27/05/1729.

${ }^{120}$ ACSM, LN 01, 03; 04; 07; 09; 10; 13; 14; 26; 29; 30; 31; 32; 33; 34, EPB.
} 
capitania baiana, com traficantes, militares de altas patentes, bacharéis, doutores, desembargadores da Relação, guardas-mores da Relação etc. Todos às voltas, na capitania fluminense, com homens de negócio, mercadores, senhores de engenho e membros da nobreza da terra, familiares do Santo Ofício, fiadores de embarcações etc. Todos membros de fortes redes estabelecidas em Minas e com ramificações para além da capitania, quiçá, ultramarinas. Por fim, destaco o mais ilustre outorgante do mestre-de-campo Manoel de Queirós Monteiro: o governador da capitania mineira, d. Brás Baltasar da Silveira. ${ }^{121}$ Além do mestrede-campo, também representavam os interesses do governador, o sargento-mor Luis Tenório de Molina, o coronel Caetano Álvares Rodrigues e o mestre-decampo Pascoal da Silva Guimarães. Conforme já foi dito certa vez: a nobreza "vive em bandos"...122

Recebido: setembro/2007 - Aprovado: setembro/2008

\footnotetext{
${ }^{121}$ ACSM, LN 07, EPB, 10/10/1717.

${ }^{122}$ FRAGOSO, João. A nobreza vive em bandos: a economia política das melhores famílias da terra do Rio de Janeiro, século XVII - algumas notas de pesquisa. Revista Tempo. Niterói, vol. 15, 2003, p. 11- 35. Mais recentemente, FRAGOSO, João Luis Ribeiro. À espera das frotas: a micro-história tapuia e a nobreza principal da terra (Rio de Janeiro, 1600-1750). PPGHIS: Rio de Janeiro, 2005, passim (Tese de professor titular).
} 